\title{
Assessing the Impacts of Market Failures on Innovation Investment in Uruguay
}

\author{
Daniel Bukstein ${ }^{1 *}$, Elisa Hernández $z^{1}$ X Ximena Usher ${ }^{1}$
}

\begin{abstract}
This paper analyzes the effects of financial and nonfinancial obstacles to innovation on Uruguayan firms. We contribute to the literature by including the role of systemic and institutional factors affecting the different stages of the innovation process. The empirical analysis is based on four waves of national innovation surveys covering firms in the industry and services sector. In line with recent studies, we confine our analysis to the relevant sample of potentially innovative firms. Our results show that market, financial, knowledge, and context obstacles are the most important factors reducing innovation propensity and the amount invested in innovation activities. The effects are similar for firms in the industry and services sectors. We do not find evidence that institutional factors hamper innovation. Investment in equipment and investment in R\&D and other intangible activities are affected differently by obstacles. On the other hand, innovation outcomes are affected mainly by financial and marketrelated barriers. We do not find evidence that obstacles to innovation have a significant impact on labor productivity.
\end{abstract}

Keywords: CDM model; financial and non-financial barriers to innovation; innovative firms; Uruguay

\section{Introduction}

In the last century, theoretical and empirical works have identified innovation (mainly proxied by R\&D investment) as a key driving force of firm productivity and economic growth. Theoretically, since the pioneering work of Solow (1957), technological change has been credited with explaining a substantial share of economic growth, while empirical developments focusing on the relationship between $R \& D$ expenditure and productivity have flourished since the seminal work of Griliches (1979). Since then, several Latin American and Caribbean (LAC) countries have established and implemented public policies aimed at enhancing innovation (Crespi and Dutrénit, 2014). However, while much attention was paid to the determinants of firm's innovation and the impact of the policy actions to promote innovation on investment and firm productivity, the analysis of the factors behind the lack of engagement on innovation activities has been neglected.

Even though there are several studies that focus on innovation and Science and Technology (STI) policies in Uruguay (Bernheim et al., 2014; Aboal et al., 2015; Bukstein et al., 2017, among others), none of them focus on what prevents the firm from engaging in innovative activities or obtaining results from their innovation efforts. As Bianchi, Bianco, and Snoeck (2014) point out, Uruguayan policymakers lack information about obstacles hampering innovation in productive sectors. Exploring the factors hampering innovation is relevant in the design of policy interventions and the national systems of innovation (Woolthius, Lankhuizen, and Gilsing, 2005). The proper identification of which obstacles affect each part of the innovation process could encourage specific interventions that may lead to an increase in economic growth and development in the long run. In that sense, we expect that the evidence presented in this paper will become a key input in the future design of policy actions.

The main objectives of this study are: (i) to test and measure to what extent barriers hinder innovation in a developing country such as
Uruguay, with a focus on context and institutional barriers; (ii) to compare whether the severity of the barriers vary across different economic sectors; and (iii) to compare whether barriers are relatively more important for tangible investments than intangible ones. We add to the literature of barriers to innovation in two ways. On the one hand, we analyze the effect of barriers to innovation on the entire chain of the innovation process: innovation propensity, innovation intensity, innovation outputs, and labor productivity. We do so separately for firms in the industry sector and the services sector. Secondly, we introduce a specific variable to measure how the institutional context affects the innovation process. This intends to shed some light on the effects of regulation and systemic factors affecting the firms' innovative behavior. We use a novel dataset covering all industries and some services of firms in the Uruguayan economy, which allows us to investigate the heterogeneous effects of barriers by sector and type of innovation.

We report that barriers to innovation have a substantial effect on innovation propensity, innovation intensity, and innovation outcomes. On the other hand, we do not find evidence that barriers affect labor productivity. The presence of obstacles to innovation translates to a reduction of 47 percent to 89 percent in the firms' innovation efforts; also, it translates to a reduction of 6.5 percent to 14 percent in the firms' innovation propensity. Financial, market, knowledge, and context obstacles are the most important factors distressing the innovation process, as they reduce the probability of engaging in innovation activities and the amount invested as well as innovation outcomes. The results indicate that barriers affect firms in the industry and services sector in a similar way.

The paper proceeds as follows. Section 2 provides a brief review of the recent developments in the literature on barriers to innovation. In Section 3, we introduce the data and methodological aspects of the paper. Section 4 shows the results of the econometric exercises; in section 6 we discuss the implications of our results. Finally, Section 6 concludes.

1) Unidad de Evaluación y Monitoreo, Agencia Nacional de Investigación e Innovación and Facultad de Administración y Ciencias Sociales, Universidad ORT Uruguay.

${ }^{*}$ Corresponding author: dbukstein@anii.org.uy

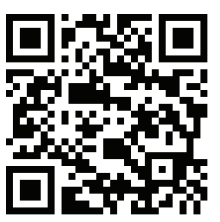




\section{Literature Review}

The empirical literature analyzing obstacles to innovation in the past decades was dedicated mostly to the role of financial constraints (Himmelberg and Petersen, 1994; Bond, Harhoff, and Van Reenen, 1999; Hall, 2002; Hall, 2008). Most of these papers use data on investment and cash flows and measure the effects of financial obstacles on innovation indirectly through the sensitivity between the latter and the former. This strand of the literature highlights that the intrinsic degree of uncertainty that characterizes innovation projects, together with their complexity, makes firms less likely to invest in innovation in the absence of financial availability (Hottenrott and Peters, 2012). Other recent contributions in this line use innovation survey data and provide direct information on the role of financial obstacles. Most of these studies are based on data from the European Community Innovation Survey (CIS) and Canadian data. Tourigny and Le (2004) study the perception of these obstacles among Canadian SMEs. Savignac (2008) finds that financial constraints and weak access to credit significantly reduce the likelihood of introducing new innovations, while Canepa and Stoneman (2007) find that the effects of credit constraints vary between sector and dimension of firms in the United Kingdom. Mancusi and Vezzulli $(2010,2013)$ measure the effects of financial constraints in R\&D investment in Italy. An important feature of innovation survey data that attracted the attention of scholars to this area of study is that it allows for a direct measure of the perception of obstacles by the firms. In this line, Mohnen and Rosa (2001) try to explain why Canadian firms perceive the obstacles to innovation differently. Galia and Legros (2004) study the perception of obstacles and complementarities in France.

More recent studies widened the scope of the analysis as they included in the picture obstacles not related to finance such as market structure, demand uncertainty, and lack of skilled personnel, among others (Iammarino, Sanna-Randaccio, and Savona, 2009; D'Este et al., 2012; D’Este, Rentocchini, and Vega-Jurado, 2014; Segarra-Blasco, García-Quevedo, and Teruel-Carrizosa, 2008; Pellegrino and Savona, 2017). Methodologically, there has been a turning point in the literature with the definition of the "relevant sample" of firms willing to innovate. A large part of the empirical literature, including studies mentioned above, finds a counterintuitive positive correlation between innovative behavior and obstacles to innovation (Mohnen and Rosa, 2001; Baldwin and Lin, 2002; Galia and Legros, 2004). Each of these studies tried to make sense of these counterintuitive findings in different ways, but they all converge in the concept of "revealed barriers," which implies that the more a firm participates in the innovation process, the more aware of the obstacles it becomes. However, recent papers (D'Este et al., 2012; Pellegrino and Savona, 2017) provide a more convincing mechanism to tackle this issue and generate consistent results, which involves excluding the firms not willing to innovate from the sample used in the empirical exercises. In the next section, we explain the construction of the relevant sample in this paper following this procedure.

Another important feature of recent literature that analyzes the role of a broad measure of obstacles and that we will address in the present study is the inclusion of the concept of "systemic failure." This concept arises when considering that not only financial barriers but also many other factors hinder innovation efforts. Consequently, the problem is not concentrated in a particular sector (e.g., financial markets), but expanded along with the economy and the national system of innovation as a whole. In that sense and according to Coad, Pellegrino, and Savona (2016), "the presence of barriers to innovation is not just the result of a 'market failure' problem, rather it might be associated with particular conditions that represent 'systemic failures' for firms, which are difficult to overcome and might be seriously detrimental to their innovation and productivity performance, making the topic of substantial policy relevance." Following D'Este, Rentocchini, and Vega-Jurado (2014), we define systemic failures in terms of the extent to which institutional factors weaken the capabilities of the firms to engage in innovative activities. Systemic failures to innovation include: (i) the lack of institutional support for innovation; (ii) the lack of information on technological and market opportunities for innovation; (iii) the lack of adequate infrastructure; and (iv) market structure factors.

Finally, regarding obstacles to innovation in Latin America, the evidence is scarce. Álvarez and Crespi (2015) use innovation surveys to measure the effect of financial constraints on innovation using a sample of Chilean firms. They find that financial barriers are quantitatively important, especially for firms operating in the services sector. Mohan, Stroble, and Watson (2017) measure the effects of obstacles on innovation propensity, intensity, innovation outcomes, and labor productivity using a sample of Caribbean firms. They find that cost, knowledge, market, and policy obstacles hamper engagement in innovation activities, innovation investment, and innovation outcomes. However, they do not find that obstacles reduce labor productivity.

\section{Data and Methodology}

\subsection{Dataset}

The data used in this paper comes from national Innovation Surveys (IS). IS is one of the largest-scale surveys gathering information on innovation behavior and outcomes. The IS in Uruguay has been carried out every three years since 1998 and is conducted by the National Bureau of Statistics (INE) as a request by the National Agency for Research and Innovation of Uruguay (ANII). The first waves only included firms in the manufacturing industry. Since the 2004-06 wave, the IS has included firms from some services sectors.

The universe of study is firms that employed at least five people or had sales greater than or equal to 120 million pesos (current USD $4.2 \mathrm{mi}-$ llion) in the period. Since 2004 the IS includes the following sectors (based on ISIC Rev.4): manufacturing; electricity, gas, steam, and airconditioning supply; water supply, sewerage, waste management and remediation activities; transportation and storage; accommodation and food service activities; information and communication; professional, scientific, and technical activities; administrative and support service activities; and human health and social work activities. Table A1 in the Appendix shows the sectoral composition of the firms.

The empirical analysis will be based on a panel data of firms from the IS observed in all periods: 2004-06, 2007-09, 2010-12, 2013-15. As we observe all firms across all years we work with a balanced panel. The decision to use a balanced panel is because the sample design that 
the INE uses, which is a rotating panel. That is each wave of the survey. The statistics bureau follows the larger part of the sample while randomly rotating approximately $25 \%$ of the sample ensuring that ISIC sector representation is maintained. While the random nature of the attrition would make the unbalanced version of the panel almost equivalent to the balanced panel in terms of its econometric treatment (Wooldridge, 2010), we choose to work with the balanced version in order to focus in the theoretical and empirical implication of the regressions, leaving aside the treatment of the sample selection that arises in these cases.

The panel data comprises a set of general information (main industry of affiliation, turnover, employment, and founding year) and a broader set of innovation variables measuring the firms' engagement in innovation activity, economic measures of the effects of innovation, subjective evaluations of factors hampering or fostering innovation, cooperative innovation activities, organizational innovation, and marketing. While general information on the firm was requested for each year in the surveys of 2010-12 and 2013-15 and for the last year of the survey for 2004-06 and 2007-09, innovation engagement variables are requested for the whole period. Therefore, while for the continuous variables, we have eight years of information, the innovation-related variables are requested in such a fashion that we can only build a fourperiod panel. In order to adjust the span of the variables, we take the 2010-12 and 2013-15 averages of the general information variables when necessary so that we have four periods of data for them.

\subsection{Sample Selection of Innovative Firms}

As mentioned above, the definition of the relevant sample of firms to be included in the empirical analysis has become a milestone in the literature of barriers to innovation. Savignac (2008), D'Este et al. (2012), Blanchard et al. (2012), and Pellegrino and Savona (2017) have shown that filtering out firms that do not want to innovate removes the positive correlation found between firms' innovation efforts and obstacles to innovation found in earlier papers such as Baldwin and Lin (2002) and Iammarino, Sanna-Randaccio, and Savona (2009). Hence, we will follow these recent developments and confine our analysis to the relevant sample of potential innovators that either engaged in innovation activities (reported non-zero innovation investment) or reported at least one barrier to the innovation of "high importance." Three categories of firms were identified in terms of their innovative status:

1. Innovative firms: reported non-zero innovation investment regardless of whether they faced obstacles to innovate

2. Failed innovators: reported at least one barrier as important but did not report innovation investment

3. Firms not willing to innovate: did not report any barriers nor do they engage in innovation activities

In order to correctly estimate the sign and size of the relationship between innovation and barriers to innovation, the relevant sample included innovative firms and failed innovators, and excluded firms not willing to innovate. The raw database includes 690 firms and 2,760 firm-year observations. We exclude from these firms 11 publicly owned companies because, as Table A2 in the Appendix shows, they are much larger than the rest of the firms and also because the fundamentals of innovation investment spending in state-owned companies differ from private companies so the effects of barriers to innovation can be expected to be different as well. ${ }^{1}$ After excluding publicly-owned firms and observations that do not fall under the relevant sample, we end up with a panel of 2,235 firm-year observations that fall under one of the three categories defined above. Figure 1 shows the distribution of the observations regarding their status in the sample. Almost 83 percent $(2,235)$ of total observations are included in the relevant sample. Within the innovative sample of firms, 1,435 reported investments in innovation activities, while 800 declared to have faced at least one barrier to innovation while they did not engage in innovation activities.

It is important to stress that even though we correct for this known source of bias, other sources of endogeneity may emerge, for example, if successful innovators and failed innovators value the importance of obstacles to innovation differently. Also, it is important to note that, as in most micro-panels that follow enterprises over the years, our sample shows a moderate bias towards larger firms that survive along the four periods of the IS. Therefore, the results should be interpreted accordingly. Next, we detail our definitions of the barriers to innovation to be included in the empirical analysis.

Figure 1: Selection of the Relevant Sample

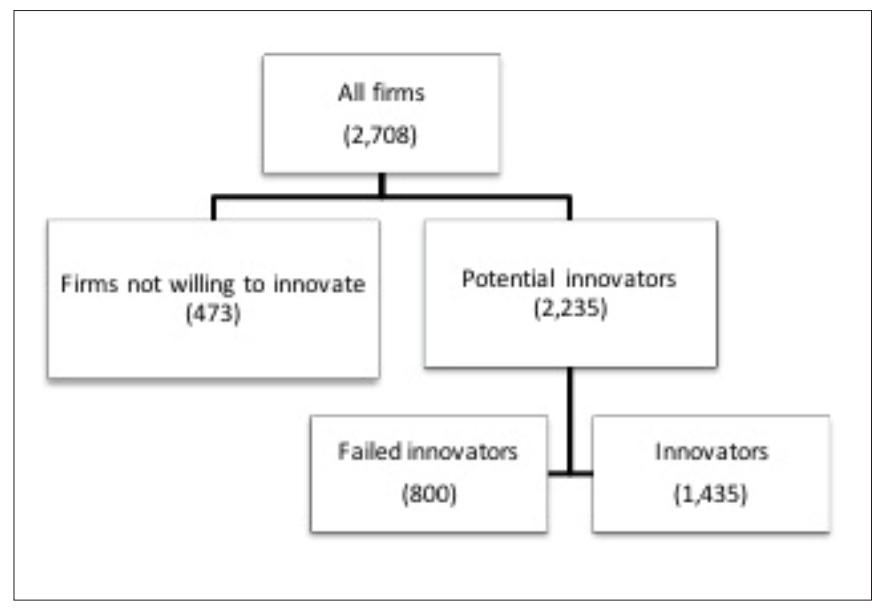

Source: Author's elaboration.

\subsection{Obstacles}

The IS questionnaire asks about 14 different obstacles to innovation. Firms are asked to respond in a 1 to 4 Likert-type scale if each obstacle was of an irrelevant, low, medium, or high importance in the process of trying to perform innovation activities, with 1 being high importance and 4 irrelevant. In this paper we will define that a firm declares the obstacle is present if it is declared as being of high importance.

\footnotetext{
${ }^{1}$ In Uruguay, state-owned enterprises are an important part of the government instruments to execute public policy and are mostly monopolies. Therefore, the rationale of the innovation decisions in these firms and the obstacles faced by them may not be comparable with those of the firms in the private sector.
} 
Note that the questionnaire asks about a broad number of factors that may have affected the innovation process. Using all of these separately would result in the construction of 14 obstacles variables. However, we choose to work a more parsimonious approach and build five dummy variables that take the value of 1 if firms faced barriers to innovation related to: 1) financial factors, 2) knowledge factors, 3) market size and structure factors, 4) institutional STI factors, and 5) context.

1. Financial obstacles: Dummy $=1$ if the firm indicates the following barriers as being of high importance: cost of finance, excessive economic risks, return period of investment risks, and 0 otherwise.

2. Knowledge obstacles: Dummy $=1$ if the firm indicates high importance in the following barriers: lack of qualified personnel, lack of information on technology, lack of information on markets, organizational rigidity, poor cooperation possibilities with other firms/institutions, and 0 otherwise.

3. Market size and structure obstacles: Dummy $=1$ if the firm indicates the following barriers as being of high importance: reduced market size, few technological opportunities of the sector, and 0 otherwise.

4. Institutional STI obstacles: Dummy $=1$ if the firm indicates the following barriers as being of high importance: insufficient development of institutions related to science and technology, poor intellectual property system, and 0 otherwise.

5. Context obstacles: Dummy $=1$ if the firm indicates the following barriers as being of high importance: inadequate infrastructure, macroeconomic instability, and 0 otherwise.

\subsection{Econometric Model and Empirical Implementation}

The methodology builds largely on Crespi and Zuñiga (2012) and Mohan, Stroble, and Watson (2017). Given that our goal is to measure the effect of obstacles to innovation on innovation propensity, innovation intensity, innovation outputs, and labor productivity, we need a model that captures the complex relationships between these variables. Therefore, we adapt the CDM model (Crepon, Duguet, and Mairesse, 1998) with the explanatory variables used in the recent literature of obstacles to innovation. The model consists of a system of five equations linking a firm's innovation activities investments to its innovation output, and its innovation output to productivity. The CDM model allows us to deal with the selection bias in the innovation effort that results from the definition of the relevant sample, as the firms that invest in innovation activities can be thought of as a non-random sample of the firms. Empirically, we estimate the model sequentially in three steps. We begin by modeling the firms' innovation effort $I E^{\star}$ by:

$I E^{\star}=\beta_{1} Z+\beta_{2} X_{1}+\varepsilon_{1}(1)$

where is a latent variable accounting for desired expenditures in innovation activities, the vector of obstacles to innovation defined above, and a vector of other covariates that explain expenditure in innovation activities. We proxy innovation effort using $(\log )$ total expenditure in innovation activities per worker as our dependent variable but we also distinguish between (log) expenditure in tangible activities per worker (expenditure in machinery, hardware, and software for innovation) and (log) expenditure in intangible activities $(\mathrm{R} \& \mathrm{D}$, technology transfers, industrial design and engineering, organizational design, training, and market research). Next, we introduce a selection equation that models the probability of observing investment in innovation activities:

$$
I D=\left\{\begin{array}{l}
1 \text { if } I D^{*}=\beta_{1} Z+\beta_{2} X_{2}+\varepsilon_{2}>\alpha \\
0 \text { if } I D^{*}=\beta_{1} Z+\beta_{2} X_{2}+\varepsilon_{2}<\alpha
\end{array}\right.
$$

where $I D$ is a binary variable that equals 1 if a firm reports investment in innovation activities greater than zero and 0 otherwise. is a latent variable modeling the firm's innovation decision which materializes if it is above the threshold level and where is a vector of barriers to innovation and are vectors of covariates affecting the innovation investment decision analogous to the ones in the previous equation.

As we only observe the amount invested for firms willing to engage in innovation activities, we combine equations (1) and (2) and write:

$$
I E=\left\{\begin{array}{c}
I E^{*}=\beta_{1} Z_{i}+\beta_{2} X+\varepsilon_{1} \text { if ID }=1 \\
0 \text { if ID }=0
\end{array}\right.
$$

Assuming that the error terms and are bivariate normal distributed with zero mean, and correlation coefficient we estimate the system of equations (2) and (3) as a type II Tobit model.

The next equation provides the link between investment in innovation activities and innovation results through the so-called "knowledge production function” (Griliches, 1979; Pakes and Griliches, 1984) where the predicted values of the innovation effort enter as one of the covariates in the equation:

$I O=\gamma I E^{\star}+\beta_{1} Z+\beta_{3} X_{3}+\mathrm{u}_{\mathrm{i}}(4)$

Where $I O$ is an innovation output and $I E^{\star}$ the predicted innovation effort from the previous step. We define three types of innovation outputs: a general definition of innovation, technological innovation (product or process innovation), and non-technological innovation (organizational and marketing). The last equation of the model relates labor productivity with innovation results:

$\mathrm{y}=\varphi I O^{\star}+\beta_{1} \mathrm{Z}+\beta_{4} \mathrm{X}_{4}+\mathrm{u}(5)$

where $y$ is labor productivity measured by the natural logarithm of sales per employee, ${ }^{2} I^{*}$ the predicted innovation output from equation (4), and $Z$ the vector of obstacles to innovation.

We estimate this recursive model in the following way. First, we estimate the generalized Tobit model of equations (2) and (3) using the Heckit procedure. Note that in this case we are not using a panel-data specific method of estimation, and we are not including fixed effects; therefore, we control for individual heterogeneity that could bias the estimation as a function of observables following Mundlak's (1978)

\footnotetext{
${ }^{2}$ Unfortunately, we do not have access to data on capital assets and therefore we cannot measure total factor productivity or include the capital per worker as a covariate as in other papers using the CDM model.
} 
approach including the within means of the explanatory variables (i.e., the average values of the covariates across all time periods for every firm) as regressors. The covariates included in the estimation of (2) and (3) are the natural logarithm of the firm's size measured by the number of employees, the natural logarithm of the firm's age, the proportion of highly skilled workers, and a dummy for exporter status, with the caveat that we remove the (log) size from the innovation effort equation in order to achieve identification because the investment is already scaled for size. We estimate equation (4) using a random-effects probit model also including the within means of the covariates to control for individual time-invariant characteristics of the firms. The additional regressors included in (4) are (log) size, exporter status, and proportion of highly skilled workers. Finally, we estimate equation (5) using a fixed-effects regression. We use the broad definition of innovator in order to calculate the predicted value of $I O$ in equation (5). In this equation, the only additional covariate is the (log) size. All regressions include year dummies. In each stage we run the regressions for all the firms in the relevant sample and repeat the exercise separately for the industry and services sector.

\subsection{Descriptive Evidence}

Tables 1 and 2 show descriptive statistics for the firms in the different sample categories and by sector respectively. In the top panel we describe the dependent variables in the regressions. The data indicate that the average firm in the sample invests USD 2,113 per year per worker in total innovation activities; however, note that the sub-sample of innovators spends twice that figure. Investment in tangible activities is the most important expenditure as it accounts for 85 percent of total investment. It is important to note the large standard deviations in the productivity variable, an issue that will be addressed below. Process innovation is the one with a higher prevalence; 70 percent of innovators successfully introduce these types of innovations. Also note that 98 percent of the firms engaged in innovation activities successfully introduce a technological or non-technological innovation. In the middle panel we report the descriptive statistics for the obstacle's dummy variables, as defined above. The most interesting result lies in the proportion of firms declaring facing obstacles in each sub-sample of innovative firms. The fact that innovators declare consistently lower obstacles than failed innovators is in line with the concept of deterring barriers (D'Este et al., 2012), as a larger involvement in innovation activities is associated with lower barriers to innovation. Regarding the explanatory variables, innovators appear older, larger, more export-oriented, and with a higher proportion of skilled workers within the firms. Results in Table 2 indicate that failed innovators and innovators in the industry sector appear to be more constrained by obstacles than firms in the services sector.

Table 1: Descriptive Statistics by Firm Category in the Sample

\begin{tabular}{|c|c|c|c|c|c|c|c|c|c|}
\hline \multirow{2}{*}{ Dependent Variables } & \multicolumn{3}{|c|}{ Total Sample } & \multicolumn{3}{|c|}{ Failed Innovator } & \multicolumn{3}{|c|}{ Innovator } \\
\hline & Mean & SD & $\mathbf{n}$ & Mean & SD & $\mathbf{n}$ & Mean & SD & $\mathbf{n}$ \\
\hline Total investment in innovation activities & 2,113 & 19,088 & 2,708 & 0 & 0 & 800 & 3,988 & 26,083 & 1,435 \\
\hline Investment in Tangibles & 1,796 & 18,990 & 2,708 & 0 & 0 & 800 & 3,390 & 25,988 & 1,435 \\
\hline Investment in Intangibles & 316 & 1,195 & 2,708 & 0 & 0 & 800 & 597 & 1,590 & 1,435 \\
\hline ln (Total investment in innovation activities) & 6.48 & 2.00 & 1,435 & & & & 6.48 & 2.00 & 1,435 \\
\hline ln (Investment in Tangibles) & 6.29 & 2.08 & 1,174 & & & & 6.29 & 2.08 & 1,174 \\
\hline ln (Investment in Intangibles) & 5.03 & 2.43 & 1,120 & & & & 5.03 & 2.43 & 1,120 \\
\hline Productivity & 128,014 & 326,805 & 2,708 & 100,311 & 281,159 & 800 & 127,751 & 247,452 & 1,435 \\
\hline $\ln$ (Productivity) & 10.98 & 1.21 & 2,708 & 10.70 & 1.24 & 800 & 11.13 & 1.11 & 1,435 \\
\hline Innovator & $52 \%$ & $50 \%$ & 2,708 & 0 & 0 & 800 & $98 \%$ & $14 \%$ & 1,435 \\
\hline Product & $27 \%$ & $44 \%$ & 2,708 & 0 & 0 & 800 & $50 \%$ & $50 \%$ & 1,435 \\
\hline Process & $37 \%$ & $48 \%$ & 2,708 & 0 & 0 & 800 & $70 \%$ & $46 \%$ & 1,435 \\
\hline Organizational & $23 \%$ & $42 \%$ & 2,708 & 0 & 0 & 800 & $43 \%$ & $50 \%$ & 1,435 \\
\hline Marketing & $11 \%$ & $31 \%$ & 2,708 & 0 & 0 & 800 & $21 \%$ & $40 \%$ & 1,435 \\
\hline \multicolumn{10}{|l|}{ Obstacles } \\
\hline Financial obstacles & $36 \%$ & $48 \%$ & 2.708 & $59 \%$ & $49 \%$ & 800 & $36 \%$ & $48 \%$ & 1,435 \\
\hline Knowledge obstacles & $32 \%$ & $47 \%$ & 2.708 & $50 \%$ & $50 \%$ & 800 & $33 \%$ & $47 \%$ & 1,435 \\
\hline Market obstacles & $38 \%$ & $49 \%$ & 2.708 & $60 \%$ & $49 \%$ & 800 & $38 \%$ & $49 \%$ & 1,435 \\
\hline Institutional STI & $14 \%$ & $34 \%$ & 2.708 & $22 \%$ & $41 \%$ & 800 & $14 \%$ & $35 \%$ & 1,435 \\
\hline Context & $21 \%$ & $41 \%$ & 2.708 & $34 \%$ & $48 \%$ & 800 & $20 \%$ & $40 \%$ & 1,435 \\
\hline \multicolumn{10}{|l|}{ Explanatory Variables } \\
\hline Age & 40.43 & 21.31 & 2.708 & 38.62 & 19.16 & 800 & 42.42 & 22.83 & 1,435 \\
\hline Size & 218.38 & 484.21 & 2.708 & 148.29 & 285.66 & 800 & 277.82 & 600.57 & 1,435 \\
\hline $\ln ($ Age) & 3.56 & 0.53 & 2.708 & 3.53 & 0.52 & 800 & 3.60 & 0.55 & 1,435 \\
\hline $\ln ($ Size) & 4.57 & 1.19 & 2.708 & 4.26 & 1.14 & 800 & 4.83 & 1.16 & 1,435 \\
\hline Exporter & 0.39 & 0.49 & 2.708 & 0.30 & 0.46 & 800 & 0.46 & 0.50 & 1,435 \\
\hline High education & 7.87 & 11.79 & 2.708 & 5.92 & 9.89 & 800 & 9.02 & 11.93 & 1,435 \\
\hline
\end{tabular}

Source: Authors' calculations. 
Table 2: Descriptive Statistics by Sector and Category

\begin{tabular}{|c|c|c|c|c|c|c|c|c|c|c|c|c|}
\hline \multirow{3}{*}{ Dependent Variables } & \multicolumn{6}{|c|}{ Failed Innovator } & \multicolumn{6}{|c|}{ Innovator } \\
\hline & \multicolumn{3}{|c|}{ Industry } & \multicolumn{3}{|c|}{ Services } & \multicolumn{3}{|c|}{ Industry } & \multicolumn{3}{|c|}{ Services } \\
\hline & Mean & SD & $\mathbf{n}$ & Mean & SD & $\mathbf{n}$ & Mean & SD & $\mathbf{n}$ & Mean & SD & $\mathbf{n}$ \\
\hline $\begin{array}{l}\text { Total investment in } \\
\text { innovation activities }\end{array}$ & 0 & 0 & 426 & 0 & 0 & 374 & 3,954 & 10,567 & 860 & 4,038 & 39,148 & 575 \\
\hline $\begin{array}{l}\text { Investment in Tan- } \\
\text { gibles }\end{array}$ & 0 & 0 & 426 & 0 & 0 & 374 & 3,217 & 10,300 & 860 & 3,651 & 39,094 & 575 \\
\hline $\begin{array}{l}\text { Investment in Intan- } \\
\text { gibles }\end{array}$ & 0 & 0 & 426 & 0 & 0 & 374 & 737 & 1,863 & 860 & 387 & 1,023 & 575 \\
\hline $\begin{array}{l}\text { ln (Total investment } \\
\text { in innovation acti- } \\
\text { vities) }\end{array}$ & & & & & & & 6.93 & 1.82 & 860 & 5.81 & 2.07 & 575 \\
\hline $\begin{array}{l}\text { In (Investment in } \\
\text { Tangibles) }\end{array}$ & & & & & & & 6.76 & 1.89 & 715 & 5.56 & 2.16 & 459 \\
\hline $\begin{array}{l}\text { ln (Investment in } \\
\text { Intangibles) }\end{array}$ & & & & & & & 5.42 & 2.25 & 676 & 4.43 & 2.56 & 444 \\
\hline Productivity & 114,694 & 350,084 & 426 & 83,929 & 170,830 & 374 & 154,435 & 287,358 & 860 & 87,842 & 163,520 & 575 \\
\hline ln (Productivity) & 10.95 & 1.14 & 426 & 10.42 & 1.29 & 374 & 11.44 & 0.94 & 860 & 10.68 & 1.17 & 575 \\
\hline Innovator & 0 & 0 & 426 & 0 & 0 & 374 & $98 \%$ & $14 \%$ & 860 & $98 \%$ & $15 \%$ & 575 \\
\hline Product & 0 & 0 & 426 & 0 & 0 & 374 & $53 \%$ & $50 \%$ & 860 & $46 \%$ & $50 \%$ & 575 \\
\hline Process & 0 & 0 & 426 & 0 & 0 & 374 & $76 \%$ & $42 \%$ & 860 & $61 \%$ & $49 \%$ & 575 \\
\hline Organizational & 0 & 0 & 426 & 0 & 0 & 374 & $38 \%$ & $49 \%$ & 860 & $52 \%$ & $50 \%$ & 575 \\
\hline Marketing & 0 & 0 & 426 & 0 & 0 & 374 & $19 \%$ & $39 \%$ & 860 & $23 \%$ & $42 \%$ & 575 \\
\hline \multicolumn{13}{|l|}{ Obstacles } \\
\hline Financial obstacles & $64 \%$ & $48 \%$ & 426 & $53 \%$ & $50 \%$ & 374 & $40 \%$ & $49 \%$ & 860 & $30 \%$ & $46 \%$ & 575 \\
\hline Knowledge obstacles & $50 \%$ & $50 \%$ & 426 & $50 \%$ & $50 \%$ & 374 & $33 \%$ & $47 \%$ & 860 & $33 \%$ & $47 \%$ & 575 \\
\hline Market obstacles & $61 \%$ & $49 \%$ & 426 & $59 \%$ & $49 \%$ & 374 & $43 \%$ & $50 \%$ & 860 & $31 \%$ & $46 \%$ & 575 \\
\hline Institutional STI & $23 \%$ & $42 \%$ & 426 & $21 \%$ & $41 \%$ & 374 & $17 \%$ & $37 \%$ & 860 & $9 \%$ & $29 \%$ & 575 \\
\hline Context & $38 \%$ & $49 \%$ & 426 & $30 \%$ & $46 \%$ & 374 & $25 \%$ & $43 \%$ & 860 & $14 \%$ & $34 \%$ & 575 \\
\hline \multicolumn{13}{|l|}{ Explanatory Variables } \\
\hline Age & 42.99 & 19.43 & 426 & 33.64 & 17.60 & 374 & 45.91 & 20.82 & 860 & 37.21 & 24.66 & 575 \\
\hline Size & 100.70 & 142.96 & 426 & 202.51 & 382.07 & 374 & 180.81 & 256.18 & 860 & 422.91 & 876.18 & 575 \\
\hline $\ln$ (Age) & 3.65 & 0.50 & 426 & 3.39 & 0.50 & 374 & 3.71 & 0.51 & 860 & 3.45 & 0.57 & 575 \\
\hline $\ln ($ Size $)$ & 4.09 & 0.98 & 426 & 4.46 & 1.28 & 374 & 4.66 & 1.00 & 860 & 5.09 & 1.33 & 575 \\
\hline Exporter & 0.44 & 0.50 & 426 & 0.13 & 0.34 & 374 & 0.62 & 0.49 & 860 & 0.22 & 0.41 & 575 \\
\hline High education & 4.00 & 4.61 & 426 & 8.11 & 13.27 & 374 & 6.49 & 7.21 & 860 & 12.80 & 15.94 & 575 \\
\hline
\end{tabular}

Source: Authors' calculations. 


\section{Results}

\subsection{Results using the balanced panel}

Table 3 shows the results for the joint estimation of equations (2) and (3). ${ }^{3}$ While the top panel shows the marginal effects for the determinants of innovation propensity, the bottom panel exhibits the results for innovation investment. In the latter equation, the reported estimates are marginal effects corrected for the probability of being selected into the sample. ${ }^{4}$ The first column shows the results for the total amount of investment in innovation activities and the total firms in the relevant sample considered in this paper; that is, considering firms from both industry and service sectors. The following columns disaggregate by sector and type of innovation activities. Column 1 indicates that four of the five barriers to innovation considered affecting innovation propensity, as their coefficient turns out negative and significant from zero. These results suggest that, in general, barriers to innovation reduce from 6.5 percent to 14 percent a firm's probability of engaging in innovative activities in Uruguayan firms. Also, the results of the determinants of (log) innovation expenditure per employee indicate that barriers to innovation related to financing, knowledge, market, and context reduce 47 percent to 89 percent total innovation expenditures. Considering the full (relevant) sample, the same obstacles affect both the propensity and intensity. In this case, institutional factors do not have a significant effect on firms' behavior.

The results shown in columns 2 and 3 are quite interesting. While the coefficients of financial, market, and knowledge obstacles are significant for both sectors, context obstacles only affect the propensity to invest in innovation activities in the services sector. On the other hand, the amount invested appears to be constrained by the context factors in firms in both industry and services sectors. Then, unlike the results for the full sample, when distinguishing between sectors, we find that in the manufacturing industry, context factors are not relevant in the decision of whether to invest in innovation, but they are a consideration in terms of how much to invest. This result may suggest that policy instruments targeted for the services sectors may focus on engaging firms in innovation, while for the industry matching grants or subsidies to increase investment may provide better results (besides other programs aiming to cope with the other significant barriers).

Finally, columns 4 to 5 report the coefficients and marginal effects for the entire sample considering the decision to engage in different innovation activities (tangibles and intangibles). In this case, results should be analyzed with more scrutiny because they differ between types of innovation activity and equation considered (top and bottom panel). Regarding the probability of investing, the financial, market, knowledge, and context obstacles affect tangible investments. On the other hand, only financial, market, and context obstacles reduce the probability of spending in intangible activities. This result is similar to Álvarez and Crespi (2015), who find that financial constraints are particularly important in intangible investments in innovation. Regarding innovation investment for tangibles, the pattern of significant coefficients for innovation barriers is maintained concerning the upper panel. Financial and knowledge barriers also affect investment in this kind of innovation activity. The results in Table 3 confirm the importance of both financial and nonfinancial barriers. With respect to the other covariates, the only size turns significant to explain innovation propensity and intensity.

\footnotetext{
${ }^{3}$ In this section we show the results for the relevant sample; in Tables A3 to A5 in the Appendix we include the results for the full sample. As can be seen, filtering out the firms not willing to innovate significantly improves the estimations.

${ }^{4}$ This is performed with the yexpected option in the margins postestimation command in STATA.
} 
Table 3: Effect of Barriers to Innovation on Innovation Propensity and Intensity (relevant sample)

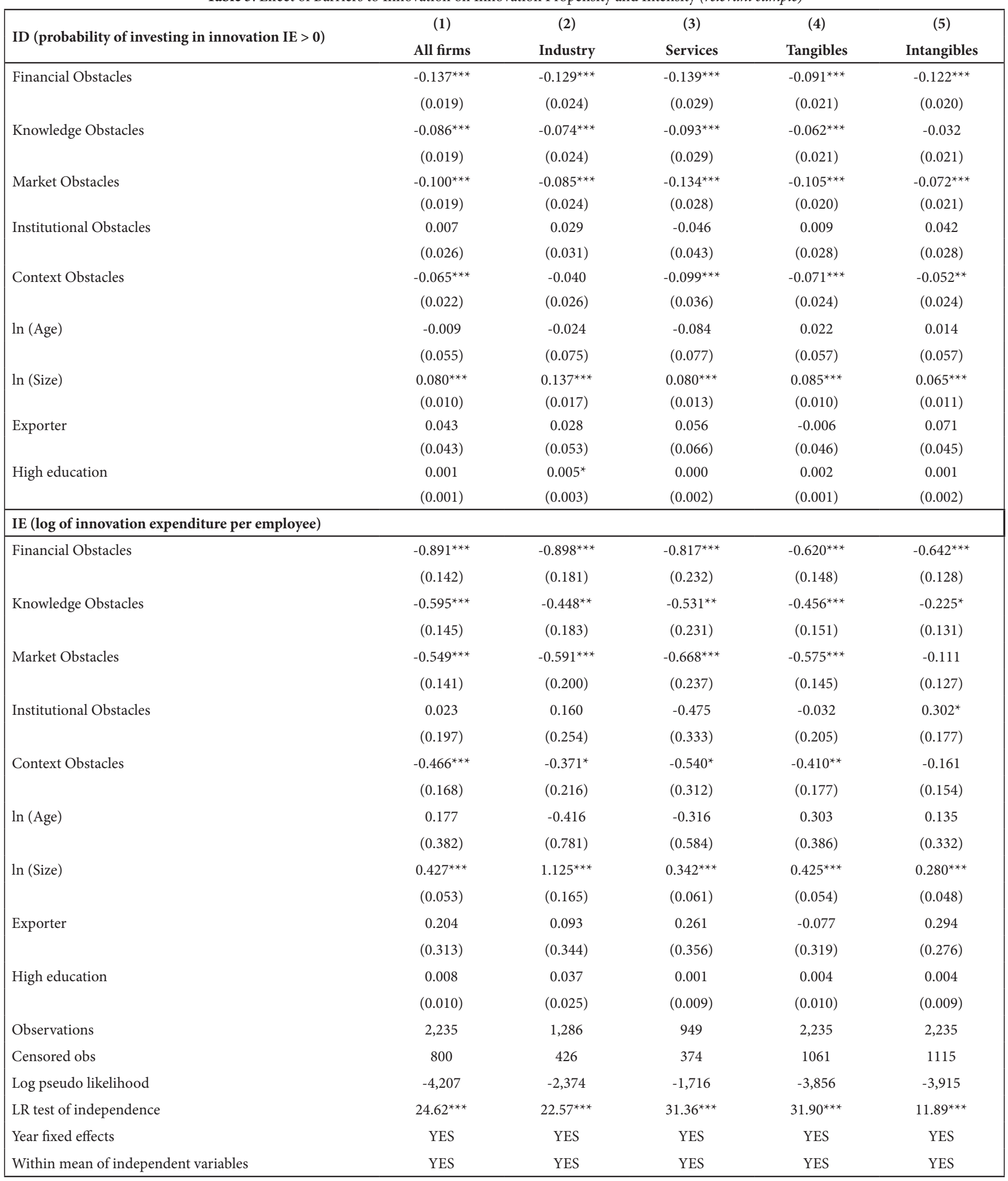

Source: Authors' calculations.

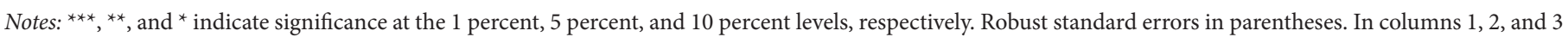

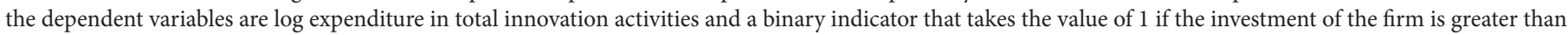
0 . Columns 4 and 5 are analogous for the investment in tangibles and intangibles activities respectively.

Table 4 illustrates the results for the estimation of the knowledge production function. We estimate the models for the general definition of innoISSN: 0718-2724. (http://jotmi.org) 
vator and then for each type of innovation (technological and non-technological innovators). For the regressions considering the full sample, we find that the predicted innovation investment is significant to explain innovation results. However, in the regressions by sector the coefficient becomes non-significant. Also, the likelihood ratio test for the significance of the individual component of the variance (rho) is significant for all the specifications, indicating that the random effects specification is suitable for the data, as opposed to the pooled estimator. Similar to the results for innovation intensity, we find that four obstacles (cost, market, knowledge, and context) reduce the probability of introducing successful innovations (Column 1). The presence of obstacles to innovation translates to a reduction of 6.5 percent to 12 percent in the firms' innovation outcomes. When considering each type of innovation separately, the results differ. While both technological and non-technological innovations are constrained by financial and market obstacles, product and process innovations are also affected by knowledge obstacles, whereas organizational and marketing innovations are affected by context obstacles. This last result is in line with Schubert (2010), who finds that the market environment affects organizational innovation.
Columns 4 to 6 and 7 to 9 show the results individually for firms in the industry and services sectors respectively. The probability of introducing new innovations for the firm in the manufacturing sector is affected by the financial, market, knowledge, and context obstacles. When considering technological innovation this last coefficient becomes non-significant. Surprisingly, non-technological innovations do not appear to be constrained by any of the obstacles considered here. Finally, columns 7 to 9 report the marginal effects for the firms in the services sector. Technological innovators face the same obstacles as in the industry sector, but the market coefficient was greater in the service sector, while non-technological innovators face financial and market constraints. This last result is interesting as non-technological innovations in the services sectors are not constrained by "soft" barriers such as knowledge but by market and financial obstacles. Regarding the rest of the covariates, the number of employees is significant to explain the introduction of innovations throughout all the specifications. The proportion of highly skilled workers enhances innovation outcomes for firms in the industry sector, while firms more export-oriented are more likely to introduce innovations in the services sector.

Table 4: Effect of Barriers to Innovation on Innovation Outcomes (relevant sample)

\begin{tabular}{|c|c|c|c|c|c|c|c|c|c|}
\hline & \multicolumn{3}{|c|}{ All Firms } & \multicolumn{3}{|c|}{ Industry } & \multicolumn{3}{|c|}{ Services } \\
\hline & (1) & (2) & (3) & (4) & (5) & (6) & (7) & (8) & (9) \\
\hline & Innovator & $\begin{array}{l}\text { Technological } \\
\text { Innovator }\end{array}$ & $\begin{array}{c}\text { Non-Tech- } \\
\text { nological } \\
\text { Innovator }\end{array}$ & Innovator & $\begin{array}{c}\text { Techno- } \\
\text { logical } \\
\text { Innovator }\end{array}$ & $\begin{array}{l}\text { Non-Tech- } \\
\text { nological } \\
\text { Innovator }\end{array}$ & Innovator & $\begin{array}{c}\text { Techno- } \\
\text { logical } \\
\text { Innovator }\end{array}$ & $\begin{array}{c}\text { Non-Tech- } \\
\text { nological } \\
\text { Innovator }\end{array}$ \\
\hline \multirow[t]{2}{*}{ IE predicted } & $0.065^{\star *}$ & $0.087^{\star * \star}$ & 0.003 & 0.010 & 0.002 & 0.039 & 0.032 & 0.005 & 0.047 \\
\hline & $(0.032)$ & $(0.033)$ & $(0.033)$ & $(0.044)$ & $(0.045)$ & $(0.045)$ & $(0.056)$ & $(0.058)$ & $(0.057)$ \\
\hline \multirow[t]{2}{*}{ Financial Obstacles } & $-0.092^{* * *}$ & $-0.080^{* * *}$ & $-0.072^{* * *}$ & $-0.114^{\star * *}$ & $-0.115^{\star * *}$ & -0.034 & $-0.103^{* * *}$ & $-0.097^{\star * *}$ & $-0.108^{\star * *}$ \\
\hline & $(0.021)$ & $(0.022)$ & $(0.022)$ & $(0.027)$ & $(0.028)$ & $(0.029)$ & $(0.033)$ & $(0.035)$ & $(0.036)$ \\
\hline \multirow[t]{2}{*}{ Knowledge Obstacles } & $-0.067^{* * *}$ & $-0.061^{\star * *}$ & 0.002 & $-0.070^{\star * *}$ & $-0.073^{* * *}$ & 0.005 & $-0.086^{* * *}$ & $-0.078^{\star *}$ & 0.001 \\
\hline & $(0.021)$ & $(0.022)$ & $(0.023)$ & $(0.027)$ & $(0.028)$ & $(0.029)$ & $(0.032)$ & $(0.035)$ & $(0.035)$ \\
\hline \multirow[t]{2}{*}{ Market Obstacles } & $-0.123^{* * *}$ & $-0.099^{* * *}$ & $-0.044^{\star *}$ & $-0.090^{* * *}$ & $-0.081^{\star * *}$ & -0.028 & $-0.181^{\star * *}$ & $-0.138^{\star * *}$ & $-0.072^{\star *}$ \\
\hline & $(0.019)$ & $(0.020)$ & $(0.021)$ & $(0.025)$ & $(0.026)$ & $(0.027)$ & $(0.027)$ & $(0.030)$ & $(0.032)$ \\
\hline \multirow[t]{2}{*}{ Institutional Obstacles } & 0.007 & 0.026 & 0.015 & 0.021 & 0.026 & 0.047 & -0.024 & 0.008 & -0.041 \\
\hline & $(0.025)$ & $(0.027)$ & $(0.028)$ & $(0.031)$ & $(0.033)$ & $(0.034)$ & $(0.042)$ & $(0.046)$ & $(0.049)$ \\
\hline \multirow[t]{2}{*}{ Context Obstacles } & $-0.055^{\star \star}$ & -0.029 & $-0.051^{\star *}$ & $-0.056^{\star *}$ & -0.025 & -0.041 & $-0.075^{\star \star}$ & $-0.082^{\star *}$ & -0.054 \\
\hline & $(0.022)$ & $(0.024)$ & $(0.025)$ & $(0.028)$ & $(0.030)$ & $(0.031)$ & $(0.037)$ & $(0.041)$ & $(0.043)$ \\
\hline \multirow[t]{2}{*}{ Exporter } & 0.056 & $0.071^{\star}$ & 0.020 & 0.005 & 0.007 & -0.054 & $0.126^{\star *}$ & $0.159^{* * *}$ & $0.121^{\star *}$ \\
\hline & $(0.037)$ & $(0.038)$ & $(0.040)$ & $(0.049)$ & $(0.051)$ & $(0.052)$ & $(0.055)$ & $(0.057)$ & $(0.061)$ \\
\hline \multirow[t]{2}{*}{$\ln ($ size $)$} & $0.070^{\star * *}$ & $0.060^{* * *}$ & $0.050^{* * *}$ & $0.143^{\star * *}$ & $0.143^{\star * *}$ & $0.056^{\star * *}$ & $0.053^{\star * *}$ & $0.037^{\star *}$ & $0.053^{\star * *}$ \\
\hline & $(0.013)$ & $(0.013)$ & $(0.012)$ & $(0.021)$ & $(0.022)$ & $(0.021)$ & $(0.018)$ & $(0.019)$ & $(0.018)$ \\
\hline \multirow[t]{2}{*}{ High education } & 0.002 & 0.000 & $0.003^{\star *}$ & $0.007^{\star \star}$ & 0.003 & $0.008^{\star * *}$ & 0.001 & -0.001 & 0.002 \\
\hline & $(0.001)$ & $(0.001)$ & $(0.001)$ & $(0.003)$ & $(0.003)$ & $(0.003)$ & $(0.001)$ & $(0.002)$ & $(0.002)$ \\
\hline Observations & 2,235 & 2,235 & 2,235 & 1,286 & 1,286 & 1,286 & 949 & 949 & 949 \\
\hline LR rho $=0$ & $116.5^{\star * \star}$ & $139.00^{* * *}$ & $32.30^{* * *}$ & $33.96^{* * *}$ & $52.42^{\star * *}$ & $9.191^{\star * *}$ & $54.82^{\star * *}$ & $48.60^{* * *}$ & $21.51^{\star * *}$ \\
\hline Year fixed effects & YES & YES & YES & YES & YES & YES & YES & YES & YES \\
\hline $\begin{array}{l}\text { Within mean of inde- } \\
\text { pendent variables }\end{array}$ & YES & YES & YES & YES & YES & YES & YES & YES & YES \\
\hline
\end{tabular}

Source: Authors' calculations. Notes: ${ }^{\star * *},{ }^{* *}$, and ${ }^{\star}$ indicate significance at the 1 percent, 5 percent, and 10 percent levels, respectively. In each column the dependent variable is a dummy that takes the value of 1 if the firm successfully introduced innovation and 0 otherwise. 
Table 5 shows the result of the labor productivity equation. Columns 1 to 3 show the results for the full (relevant) sample, where we find positive significant signs for the knowledge and market coefficients. We argue that these results may be caused by the large dispersion of the dependent variable, as shown in the previous section. In Columns 4 to 6 we show the results using a winsori- zed sample removing observations below the $5^{\text {th }}$ and above the $95^{\text {th }}$ percentile of the distributions. We find that innovation propensity had a positive but not significant impact on labor productivity. Also, there is no evidence that obstacles affect our dependent variable. These results are similar to Mohan, Stroble, and Watson (2017) for Caribbean firms.

Table 5: Effects of Barriers to Innovation on Labor Productivity

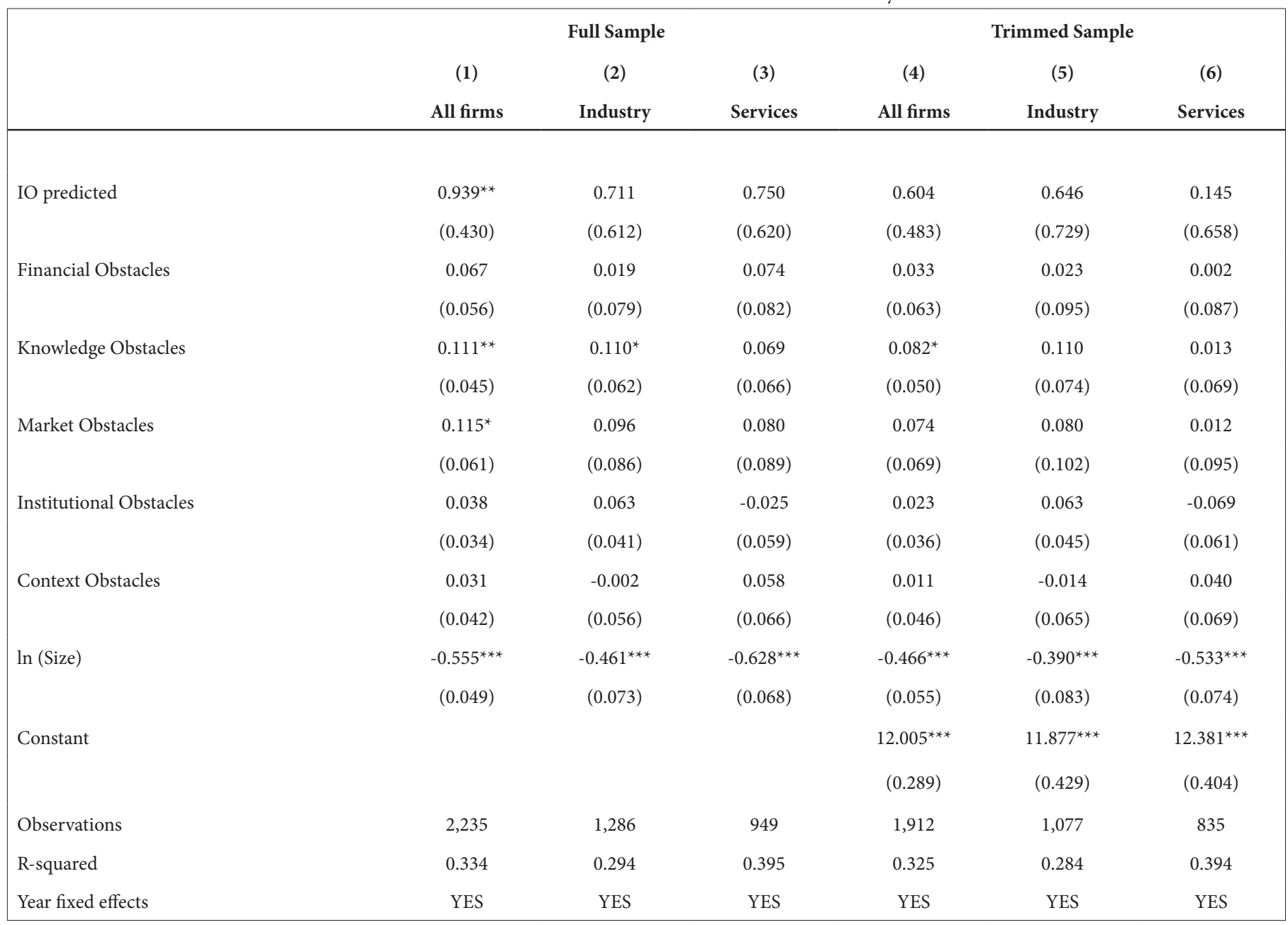

Source: Authors' calculations.

Notes: ${ }^{* *},{ }^{* *}$, and ${ }^{*}$ indicate significance at the 1 percent, 5 percent, and 10 percent levels, respectively. In all columns the dependent variable is the natural logarithm of labor productivity.

So far, we have analyzed the results of the estimations for each stage of the model separately, which can become cumbersome as the tables include several columns analyzing different sets of firms and/or innovation activities. In order to ease the interpretation of the results, we include a table with the summary of findings by estimation procedure and barrier. In summary, Table 6 helps us to draw the following conclusions relating to the relevance of each barrier in the innovation process:
- Financial obstacles appear as the most important factors hampering innovation because it is significant across almost all estimations.

- Knowledge and market obstacles affect innovation propensity to a similar extent. However, market obstacles appear more significant in the case of innovation outcomes.

- Institutional obstacles are non-significant.

- Context obstacles are more important constraints to engagement and investment than explaining failure in achieving innovation outputs. 
Table 6: Summary of Findings by Obstacle and Estimated Equation

\begin{tabular}{|c|c|c|c|c|}
\hline & Innovation Propensity & Innovation Intensity & Innovation Outcomes & Labor Productivity \\
\hline Financial & $\begin{array}{l}\text { Significant throughout all the } \\
\text { specifications }\end{array}$ & $\begin{array}{l}\text { Significant throughout all the } \\
\text { specifications }\end{array}$ & $\begin{array}{l}\text { Significant throughout all the specifications ex- } \\
\text { cept for industry non-technological innovation }\end{array}$ & Non-significant \\
\hline Knowledge & $\begin{array}{l}\text { Significant throughout all the } \\
\text { specifications except for intan- } \\
\text { gibles }\end{array}$ & $\begin{array}{l}\text { Significant throughout all the } \\
\text { specifications }\end{array}$ & $\begin{array}{l}\text { Significant in all cases for general and techno- } \\
\text { logical innovation; non-significant in any case } \\
\text { for non-technological innovation }\end{array}$ & Non-significant \\
\hline Market & $\begin{array}{l}\text { Significant throughout all the } \\
\text { specifications }\end{array}$ & $\begin{array}{l}\text { Significant throughout all the spe- } \\
\text { cifications except for intangibles }\end{array}$ & $\begin{array}{l}\text { Significant throughout all the specifications except } \\
\text { for industry non-technological innovation }\end{array}$ & Non-significant \\
\hline Institutional & Non-significant & Non-significant & Non-significant & Non-significant \\
\hline Context & $\begin{array}{l}\text { Significant throughout all the } \\
\text { specifications except for indus- } \\
\text { try firms }\end{array}$ & $\begin{array}{l}\text { Significant throughout all the } \\
\text { specifications except for intan- } \\
\text { gibles }\end{array}$ & $\begin{array}{l}\text { All firms: significant for general and non-te- } \\
\text { chnological innovation; industry: significant } \\
\text { for general innovation; services: significant } \\
\text { for general and technological innovation }\end{array}$ & Non-significant \\
\hline
\end{tabular}

Source: Authors' calculations.

Note: Coefficient significant at the 1 percent, 5 percent, and 10 percent levels.

\subsection{Robustness check: results using the unbalanced panel}

In this section, we include the econometric analysis for the unbalanced panel as a robustness test. The tables below show no to litt- le variation with respect to the results found using the balanced panel.

Table 7: Effect of Barriers to Innovation on Innovation Propensity and Intensity. Unbalanced panel. (relevant sample)

\begin{tabular}{|c|c|c|c|c|c|}
\hline ID (probability of investing in innovation IE $>0$ ) & $\begin{array}{c}(1) \\
\text { All firms }\end{array}$ & $\begin{array}{c}(2) \\
\text { Industry }\end{array}$ & $\begin{array}{c}(3) \\
\text { Services }\end{array}$ & $\begin{array}{c}(4) \\
\text { Tangibles }\end{array}$ & $\begin{array}{c}(5) \\
\text { Intangibles }\end{array}$ \\
\hline Financial Obstacles & $\begin{array}{c}-0.137^{\star \star *} \\
(0.019)\end{array}$ & $\begin{array}{c}-0.129^{\star * *} \\
(0.024)\end{array}$ & $\begin{array}{c}-0.139^{* * *} \\
(0.029)\end{array}$ & $\begin{array}{c}-0.091^{\star * *} \\
(0.021)\end{array}$ & $\begin{array}{c}-0.122^{\star * *} \\
(0.020)\end{array}$ \\
\hline Knowledge Obstacles & $\begin{array}{c}-0.086^{\star * *} \\
(0.019)\end{array}$ & $\begin{array}{c}-0.074^{\star * *} \\
(0.024)\end{array}$ & $\begin{array}{c}-0.093^{* * *} \\
(0.029)\end{array}$ & $\begin{array}{c}-0.062^{\star * *} \\
(0.021)\end{array}$ & $\begin{array}{c}-0.032 \\
(0.021)\end{array}$ \\
\hline Market Obstacles & $\begin{array}{c}-0.100^{\star * *} \\
(0.019)\end{array}$ & $\begin{array}{c}-0.085^{\star * \star} \\
(0.024)\end{array}$ & $\begin{array}{c}-0.134^{* * *} \\
(0.028)\end{array}$ & $\begin{array}{c}-0.105^{\star * *} \\
(0.020)\end{array}$ & $\begin{array}{c}-0.072^{\star * *} \\
(0.021)\end{array}$ \\
\hline Institutional Obstacles & $\begin{array}{c}0.007 \\
(0.026)\end{array}$ & $\begin{array}{c}0.029 \\
(0.031)\end{array}$ & $\begin{array}{c}-0.046 \\
(0.043)\end{array}$ & $\begin{array}{c}0.009 \\
(0.028)\end{array}$ & $\begin{array}{c}0.042 \\
(0.028)\end{array}$ \\
\hline Context Obstacles & $\begin{array}{c}-0.065^{* * *} \\
(0.022)\end{array}$ & $\begin{array}{c}-0.040 \\
(0.026)\end{array}$ & $\begin{array}{c}-0.099^{* * *} \\
(0.036)\end{array}$ & $\begin{array}{c}-0.071^{\star * *} \\
(0.024)\end{array}$ & $\begin{array}{c}-0.052^{\star *} \\
(0.024)\end{array}$ \\
\hline $\ln ($ Age $)$ & $\begin{array}{c}-0.009 \\
(0.055)\end{array}$ & $\begin{array}{c}-0.024 \\
(0.075)\end{array}$ & $\begin{array}{c}-0.084 \\
(0.077)\end{array}$ & $\begin{array}{c}0.022 \\
(0.057)\end{array}$ & $\begin{array}{c}0.014 \\
(0.057)\end{array}$ \\
\hline $\ln ($ Size) & $\begin{array}{c}0.043 \\
(0.043)\end{array}$ & $\begin{array}{c}0.028 \\
(0.053)\end{array}$ & $\begin{array}{c}0.056 \\
(0.066)\end{array}$ & $\begin{array}{c}-0.006 \\
(0.046)\end{array}$ & $\begin{array}{c}0.071 \\
(0.045)\end{array}$ \\
\hline Exporter & $\begin{array}{c}0.001 \\
(0.001)\end{array}$ & $\begin{array}{l}0.005^{\star} \\
(0.003)\end{array}$ & $\begin{array}{c}0.000 \\
(0.002)\end{array}$ & $\begin{array}{c}0.002 \\
(0.001)\end{array}$ & $\begin{array}{c}0.001 \\
(0.002)\end{array}$ \\
\hline High education & $\begin{array}{c}-0.137^{\star * *} \\
(0.019) \\
\end{array}$ & $\begin{array}{c}-0.129^{* * *} \\
(0.024)\end{array}$ & $\begin{array}{c}-0.139^{* * *} \\
(0.029) \\
\end{array}$ & $\begin{array}{c}-0.091^{\star * *} \\
(0.021)\end{array}$ & $\begin{array}{c}-0.122^{\star * *} \\
(0.020)\end{array}$ \\
\hline IE (log of innovation expenditure per employee) & & & & & \\
\hline Financial Obstacles & $\begin{array}{c}-0.945^{* * *} \\
(0.138)\end{array}$ & $\begin{array}{c}-0.985^{\star * *} \\
(0.176)\end{array}$ & $\begin{array}{c}-0.836^{\star * *} \\
(0.225)\end{array}$ & $\begin{array}{c}-0.672^{\star * *} \\
(0.143)\end{array}$ & $\begin{array}{c}-0.675^{\star * *} \\
(0.124)\end{array}$ \\
\hline Knowledge Obstacles & $\begin{array}{c}-0.568^{* * *} \\
(0.142)\end{array}$ & $\begin{array}{c}-0.408^{\star *} \\
(0.181)\end{array}$ & $\begin{array}{c}-0.518^{\star *} \\
(0.225)\end{array}$ & $\begin{array}{c}-0.432^{\star * *} \\
(0.147)\end{array}$ & $\begin{array}{c}-0.232^{*} \\
(0.128)\end{array}$ \\
\hline Market Obstacles & $\begin{array}{c}-0.589^{* * *} \\
(0.137)\end{array}$ & $\begin{array}{c}-0.660^{* * *} \\
(0.194)\end{array}$ & $\begin{array}{c}-0.670^{* * *} \\
(0.229)\end{array}$ & $\begin{array}{c}-0.623^{* * *} \\
(0.141)\end{array}$ & $\begin{array}{l}-0.140 \\
(0.123)\end{array}$ \\
\hline Institutional Obstacles & $\begin{array}{c}0.064 \\
(0.192)\end{array}$ & $\begin{array}{c}0.205 \\
(0.249)\end{array}$ & $\begin{array}{c}-0.421 \\
(0.325)\end{array}$ & $\begin{array}{c}0.038 \\
(0.198)\end{array}$ & $\begin{array}{c}0.308 \\
(0.190)\end{array}$ \\
\hline Context Obstacles & $\begin{array}{c}-0.409^{* *} \\
(0.164)\end{array}$ & $\begin{array}{l}-0.347^{\star} \\
(0.208)\end{array}$ & $\begin{array}{l}-0.454 \\
(0.301)\end{array}$ & $\begin{array}{c}-0.370^{* *} \\
(0.171)\end{array}$ & $\begin{array}{l}-0.124 \\
(0.148)\end{array}$ \\
\hline $\ln ($ Age $)$ & $\begin{array}{c}0.255 \\
(0.369)\end{array}$ & $\begin{array}{l}-0.296 \\
(0.704)\end{array}$ & $\begin{array}{l}-0.194 \\
(0.565)\end{array}$ & $\begin{array}{c}0.401 \\
(0.371)\end{array}$ & $\begin{array}{c}0.203 \\
(0.319)\end{array}$ \\
\hline $\ln ($ Size $)$ & $\begin{array}{c}0.469^{* * *} \\
(0.052)\end{array}$ & $\begin{array}{l}1.227^{\star * *} \\
(0.154)\end{array}$ & $\begin{array}{c}0.346^{* * *} \\
(0.059)\end{array}$ & $\begin{array}{c}0.462^{\star * *} \\
(0.053)\end{array}$ & $\begin{array}{c}0.306^{* * *} \\
(0.046)\end{array}$ \\
\hline Exporter & $\begin{array}{c}0.357 \\
(0.305)\end{array}$ & $\begin{array}{c}0.187 \\
(0.343)\end{array}$ & $\begin{array}{c}0.439 \\
(0.355)\end{array}$ & $\begin{array}{c}0.086 \\
(0.309)\end{array}$ & $\begin{array}{c}0.358 \\
(0.267)\end{array}$ \\
\hline High education & $\begin{array}{c}0.004 \\
(0.010)\end{array}$ & $\begin{array}{c}0.019 \\
(0.018)\end{array}$ & $\begin{array}{l}-0.001 \\
(0.009)\end{array}$ & $\begin{array}{c}0.000 \\
(0.010)\end{array}$ & $\begin{array}{c}0.002 \\
(0.009)\end{array}$ \\
\hline Observations & 2,337 & 1,342 & 995 & 2,337 & 2,337 \\
\hline Censored obs & 868 & 465 & 403 & 1138 & 1190 \\
\hline Log pseudo likelihood & $-4,342$ & $-2,441$ & $-1,787$ & $-3,856$ & $-4,033$ \\
\hline LR test of independence & $26.74^{* * *}$ & $21.65^{\star * *}$ & $29.60^{* * *}$ & $32.84^{* * *}$ & $13.51^{\star * *}$ \\
\hline Year fixed effects & YES & YES & YES & YES & YES \\
\hline Within mean of independent variables & YES & YES & YES & YES & YES \\
\hline
\end{tabular}

Source: Authors' calculations. Notes: ${ }^{* *},{ }^{* *}$, and ${ }^{\star}$ indicate significance at the 1 percent, 5 percent, and 10 percent levels, respectively. Robust standard errors in parentheses. In columns 1,2 , and 3 the dependent variables are log expenditure in total innovation activities and a binary indicator that takes the value of 1 if the investment of the firm is greater than 0 . Columns 4 and 5 are analogous for the investment in tangibles and intangibles activities respectively. 
Table 8: Effect of Barriers to Innovation on Innovation Outcomes. Balanced Sample (relevant sample)

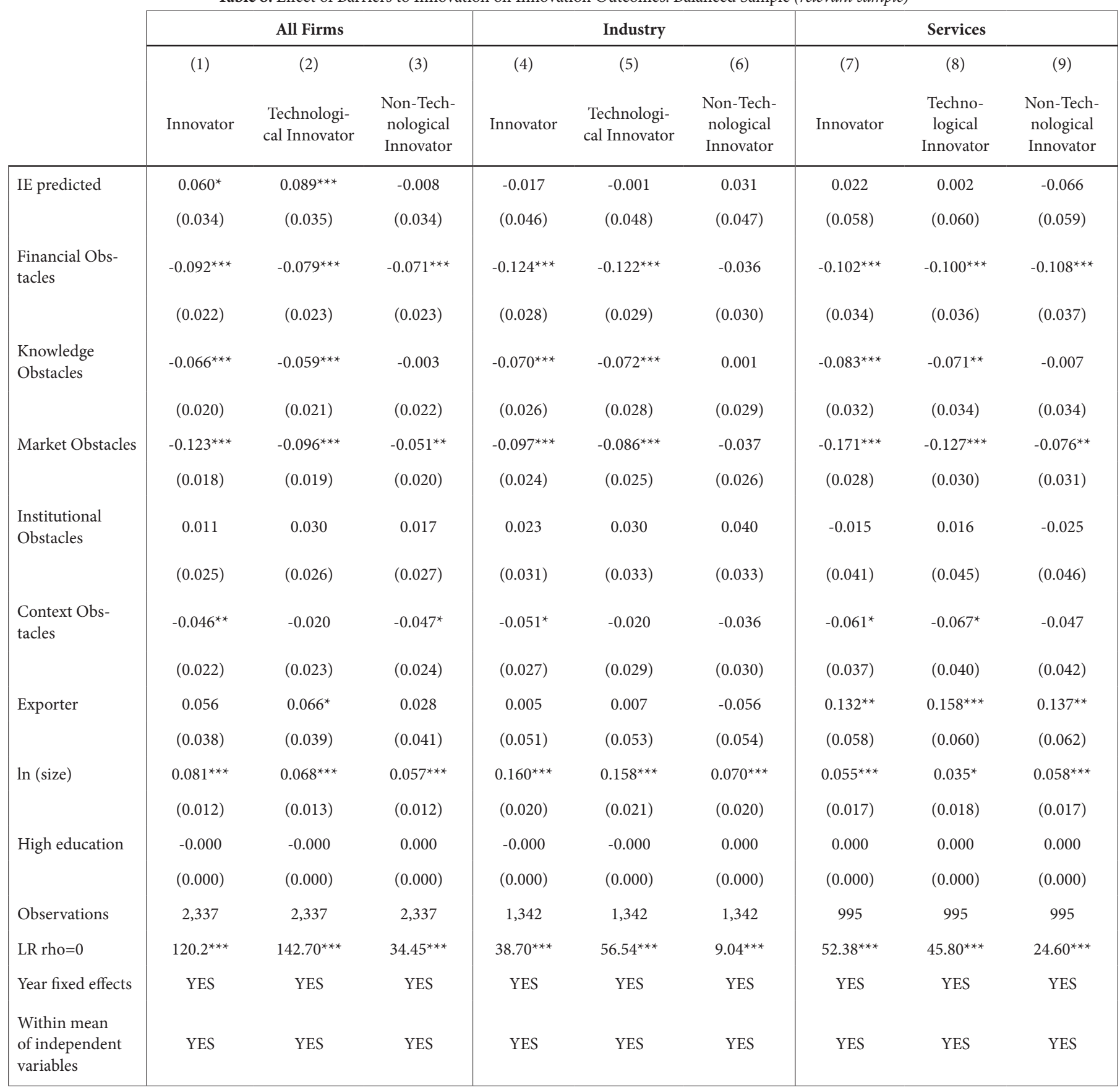

Source: Authors' calculations. Notes: ${ }^{* *},{ }^{* *}$, and ${ }^{*}$ indicate significance at the 1 percent, 5 percent, and 10 percent levels, respectively. In each column the dependent variable is a dummy that takes the value of 1 if the firm successfully introduced innovation and 0 otherwise. 
Table 5: Effects of Barriers to Innovation on Labor Productivity. Unbalanced Sample. (relevant sample)

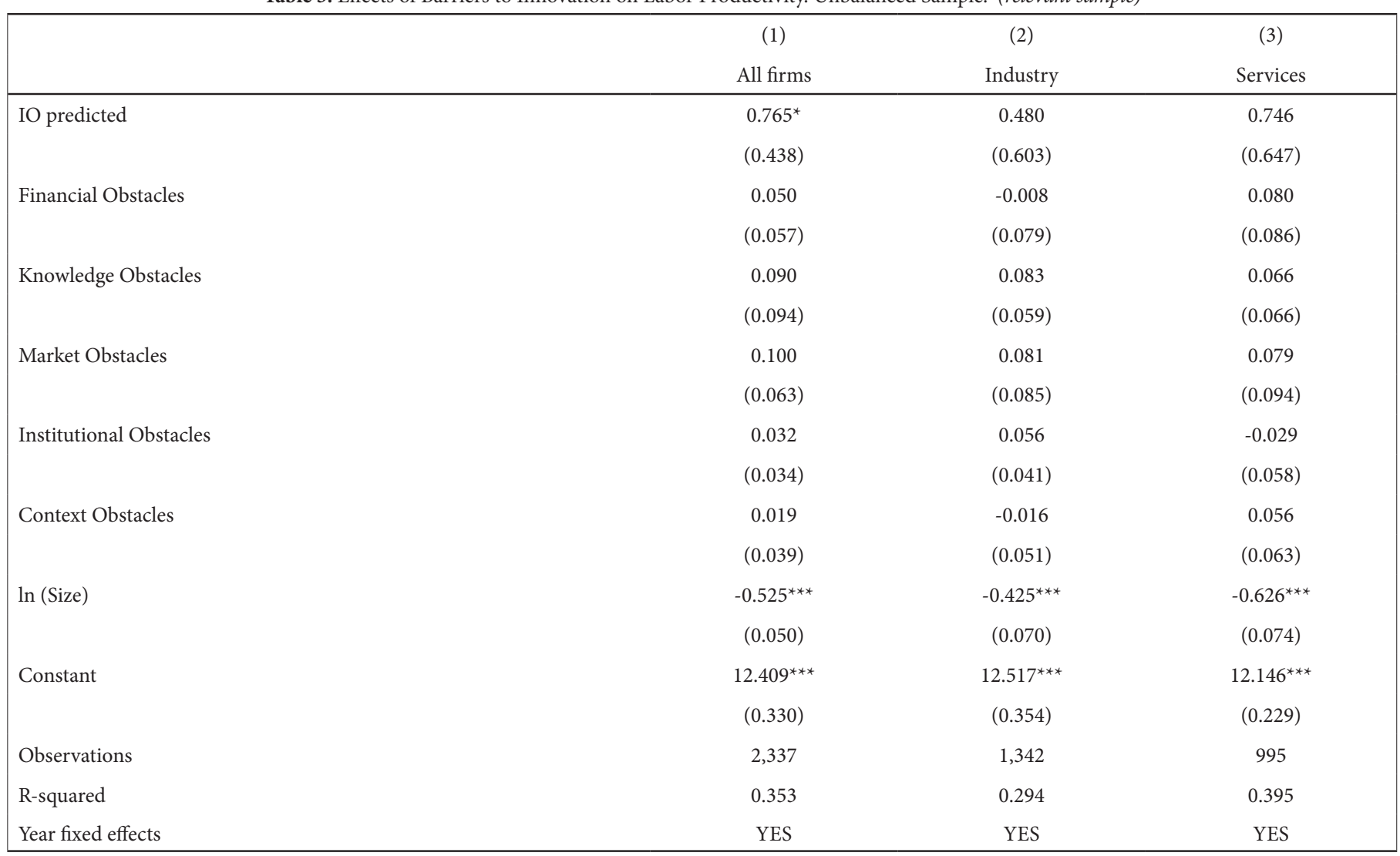

Source: Authors' calculations.

Notes: ${ }^{* *},{ }^{* *}$, and ${ }^{\star}$ indicate significance at the 1 percent, 5 percent, and 10 percent levels, respectively. In all columns the dependent variable is the natural logarithm of labor productivity.

\section{Discussion}

In this section, we analyze the implications of the results previously found.

In terms of the goals of our paper detailed in the introduction, we can argue the following. We find that obstacles to innovation are important factors reducing the innovation propensity, innovation intensity, and innovation outcomes. On the contrary, we do not find that obstacles to innovation reduce labor productivity. We believe that the fact that we do not find that obstacles affect productivity is conditioned by the large dispersion of the variable that we cannot improve even when winsorizing the sample used in the regressions. Also we believe that because of this defect of our data, labor productivity is not the best variable to use in this case. Total factor productivity or value-added per employee (the proxy variable for productivity Crepon, Duguet, and Mairesse, 1998) arise as more suitable measures of productivity and should be tested in future research.

Our estimations show that barriers to innovation impact the industry and services sectors in a similar way, while the effects found in tangible investments are larger than those in intangible ones. While we find that context obstacles are important factors hindering innovation propensity and innovation outcomes, we do not find evidence that they affect innovation intensity. This is caused by the fact that context obstacles reflect macroeconomic environment and infrastructure and thus affect the part of the innovation process most sensitive to uncertainty (the decision to innovate and innovation outcomes). On the other hand, we do not find that institutional obstacles affect any of the variables analyzed. The fact that institutional factors do not affect the innovation process should be taken as good news by policymakers. This result is in line with statements from policy actors in Latin America praising Uruguayan STI institutions (Angelelli et al., 2017).

What can be learned from these results and how can policymakers in Uruguay mitigate the effects of obstacles to innovation? Regarding financial barriers, these issues have been addressed in the last decade by ANII through a set of programs promoting innovation activities in the productive sector. An impact evaluation by Bukstein et al. (2017) shows evidence of a crowding-in effect for beneficiaries of ANII's programs, as treated firms spend two to three times more in R\&D and three to four times more in innovation activities than the control group. However, the scope of ANII is still small at the national level, with less than 1 percent of national firms engaging in this type of program. Therefore, the main challenge for policy actions in this regard is to increase the reach of instruments to foster innovation with focus in 
intangible investments. Also, promoting cooperation between firms might help reduce the costs of innovation projects as shown by Antonioli, Marzucchi, and Savona (2017). Concerning the market structure-related obstacles, this is the most challenging obstacle to overcome as its reduced size is an intrinsic characteristic of the Uruguayan market. We, therefore, infer that the lack of demand is decisive for firms to give up innovation projects. In this sense, the policy actions should focus on insertion of firms into global value chains or help in placing their products in international markets. With respect to knowledgerelated obstacles, it is necessary to foster the link between academia and industry, for example, funding the training of highly qualified professionals and aiding their insertion in the productive sectors.

Finally, results indicate that policymakers should keep in mind that macroeconomic instability and uncertainty not only harm economic performance through higher unemployment but also via preventing firms from engaging in innovation activities. In this regard, the results suggest that in times of economic downturn, policy instruments targeted for the services sectors may focus on engaging firms in innovation, while for the industry matching grants or subsidies to increase investment may provide better results (besides other programs aiming to cope with other significant barriers).

\section{Concluding Remarks}

This paper presents evidence that barriers to innovation have a substantial effect on innovation propensity, intensity, and outcomes. On the other hand, we do not find evidence that barriers affect labor productivity. In terms of the objectives of the study, we do not find evidence that institutional obstacles are important factors hampering innovation; however, it is important to note that the rest of the financial and nonfinancial barriers considered are significant. The results show that obstacles affect the innovative behavior of firms in the industry and services sectors similarly. We confirm that different barriers hamper investment in tangible and intangible activities.

The presence of obstacles to innovation translates to a reduction of 47 percent to 89 percent in the firms' innovation efforts; also, it translates to a reduction of 6.5 percent to 14 percent in the firms' innovation propensity. Financial, market, knowledge, and context obstacles are the most important factors reducing the probability to engage in innovation activities and the amount invested. On the other hand, the empirical analysis indicates that barriers related to the systemic failure of STI institutions are not significant. While expenditure on equipment is affected mainly by the four obstacles mentioned above, investment in $\mathrm{R} \& \mathrm{D}$ and other intangible activities are mostly constrained by market and financial barriers. Regarding innovation outcomes, we find that financial and market factors are the most important, whereas the role of context and knowledge barriers varies between types of innovation. Finally, we do not find effects of obstacles to innovation on labor productivity.

The evidence presented throughout this paper should serve as an input for future policymaking. From a national system of innovation perspective, it is crucial for policymakers to understand which obstacles slow down the firms' innovation process (Chaminade and Edquist, 2006). As Galia, Mancini, and Morandi (2012) point out, different types of obstacles and innovator profiles demand different interventions. Our results suggest that a systemic approach to overcome several barriers is needed. In order to increase engagement in innovation activities and expenditure intensity, a mixture of instruments focusing in financial, market, and knowledge is needed (innovation widening) along with expanding the reach of innovative activities and increasing innovation outcomes (innovation deepening). Regarding the economic sectors, the results suggest that policies can be applied broadly.

Future research topics include studying the complementarities between the barriers and other questions such as the cooperation strategy of the firms in order to cope with innovation obstacles. Also, new studies including productivity should aim to use new measures of this important variable, such as value-added per employee or total factor productivity.

\section{References}

Aboal, D. et al. 2015. Innovación en Uruguay: Diagnóstico y propuestas de política. Working paper No. 12. Montevideo, Uruguay: CINVE.

Álvarez, R., and G. A. Crespi. 2015. Heterogeneous Effects of Financial Constraints on Innovation: Evidence from Chile. Science and Public Policy 42(5): 711-724. https://doi.org/10.1093/scipol/scu091

Angelelli, P, Luna, F and Suaznabar, C. Agencias latinoamericanas de fomento de la innovación y el emprendimiento: Características y retos futuros. IADB Technical note IDB-TN-1285. http://dx.doi. org/10.18235/0000857

Antonioli, D., A. Marzucchi, and M. Savona. 2017. Pain Shared, Pain Halved? Cooperation As a Coping Strategy for Innovation Barriers. The Journal of Technology Transfer 42(4): 841-864. https:// doi.org/10.1007/s10961-016-9545-9

Baldwin, J., and Z. Lin. 2002. Impediments to Advanced Technology Adoption for Canadian Manufacturers. Research Policy 31(1): 1-18. https://doi.org/10.1016/s0048-7333(01)00110-x

Bernheim, R., D. Bukstein, E. Hernández, and X. Usher. 2014. Impacto de los instrumentos de promoción de la innovación orientada al sector productivo. Working Paper No. 7. Montevideo, Uruguay: ANII.

Bianchi, C., M. Bianco, and M. Snoeck. 2014. Value Attributed to STI Activities and Policies in Uruguay. In G. Crespi and G. Dutrénit (eds), Science, Technology and Innovation Policies for Development: The Latin American Experience. Switzerland: Springer International Publishing. https://doi.org/10.1007/978-3-319-04108-7_7

Blanchard, P., J. P. Huiban, A. Musolesi, and P. Sevestre. 2012. Where There Is a Will, There Is a Way? Assessing the Impact of Obstacles to Innovation. Industrial and Corporate Change 22(3): 679-710. https:// doi.org/10.1093/icc/dts027 
Bond, S., D. Harhoff, and J. Van Reenen. 1999. Investment, R\&D and Financial Constraints in Britain and Germany (No. W99/05). London: Institute for Fiscal Studies. https://doi.org/10.1920/wp.ifs.1999.9905

Bukstein, D. et al. 2017. Impacto de los instrumentos de promoción de la innovación orientada al sector productivo. Working paper No. 12. Montevideo, Uruguay: ANII.

Canepa, A., and P. Stoneman. 2007. Financial Constraints to Innovation in the UK: Evidence from CIS2 and CIS3. Oxford Economic Papers 60(4): 711-730. https://doi.org/10.1093/oep/gpm044

Chaminade, C., and C. Edquist. 2006. From Theory to Practice: The Use of the Systems of Innovation Approach in Innovation Policy. In J. Hage and M. Meeus (eds), Innovation, Science, and Institutional Change: A Research Handbook. Oxford: Oxford University Press.

Coad, A., G. Pellegrino, and M. Savona. 2016. Barriers to Innovation and Firm Productivity. Economics of Innovation and New Technology 25(3): 321-334. https://doi.org/10.1080/10438599.20 15.1076193

Crépon, B., E. Duguet, and J. Mairesse. 1998. Research, Innovation and Productivity: An Econometric Analysis at the Firm Level. Economics of Innovation and New Technology 7(2): 115-158. https:// doi.org/10.3386/w6696

Crespi, G., and G. Dutrénit (eds). 2014. Science, Technology and Innovation Policies for Development: The Latin American Experience. Switzerland: Springer International Publishing. https:/doi. org/10.1007/978-3-319-04108-7

Crespi, G., and P. Zuniga. 2012. Innovation and Productivity: Evidence from Six Latin American Countries. World Development 40(2): 273-290. https://doi.org/10.1016/j.worlddev.2011.07.010

D’Este, P., S. Iammarino, M. Savona, and N. von Tunzelmann. 2012. What Hampers Innovation? Revealed Barriers Versus Deterring Barriers. Research Policy 41(2): 482-488. https://doi.org/10.1016/j.respol.2011.09.008

D’Este, P., F. Rentocchini, and J. Vega-Jurado. 2014. The Role of Human Capital in Lowering the Barriers to Engaging in Innovation: Evidence from the Spanish Innovation Survey. Industry and Innovation 21(1): 1-19. https://doi.org/10.1080/13662716.2014.879252

Galia, F., and D. Legros. 2004. Complementarities between Obstacles to Innovation: Evidence from France. Research Policy 33: 1185-1199. https://doi.org/10.1016/j.respol.2004.06.004

Galia, F., S. Mancini, S., and V. Morandi. 2012. Obstacles to Innovation and Firms Innovation Profiles: Are Challenges Different for Policy Makers? Erasmus Research Institute of Management, EURAM 12th Conference, Rotterdam, June 6-8. https://doi.org/10.4995/ icbm.2015.1287
Griliches, Z. 1979. Issues in Assessing the Contribution of Research and Development to Productivity Growth. The Bell Journal of Economics 10(1): 92-116. https://doi.org/10.2307/3003321

Hall, Bronwyn H. 2002. The Financing of Research and Development. NBER Working Paper 8773. Cambridge, MA: National Bureau of Economic Research. https://doi.org/10.3386/w8773

- - 2008. The Financing of Innovation. In Scott Shane (ed), Handbook of Technology and Innovation Management. Oxford: Blackwell Publishers Ltd.

Himmelberg, C. P., and B. C. Petersen. 1994. R \& D and Internal Finance: A Panel Study of Small Firms in High-Tech Industries. The Review of Economics and Statistics, 38-51. https://doi.org/10.2307/2109824

Hottenrott, H., and B. Peters. 2012. Innovative Capability and Financing Constraints for Innovation: More Money, More Innovation? Review of Economics and Statistics 94(4): 1126-1142. https://doi. org/10.1162/rest_a_00227

Iammarino, S., R. Sanna-Randaccio, and M. Savona. 2009. The Perception of Obstacles to Innovation: Foreign Multinationals and Domestic Firms in Italy. Revue d'économie industrielle 125(1): 75-104. https://doi.org/10.4000/rei.3953

Mancusi, M. L., and A. Vezzulli. 2010. R\&D, Innovation and Liquidity Constraints. Paper presented at the CONCORD Conference, Seville, March 3-4.

- - - 2013. R\&D and Credit Rationing in SMEs. Working Paper No. 2013/12. Lisbon: Department of Economics, ISEG, Lisbon School of Economics and Management, Universidade de Lisboa. https://doi. org/10.1111/ecin.12080

Mohan, P., E. Stroble, and P. Watson. 2017. Barriers to Innovation and Firm Productivity in the Caribbean. In S. Donhert, G. Crespi, and A. Maffioli (eds), Exploring Firm-Level Innovation and Productivity in Developing Countries: The Perspective of Caribbean Small States. Washington, DC: Inter-American Development Bank. https://doi. org/10.18235/0000616

Mohnen, P., and J. Rosa. 2001. Les obstacles à l'innovation dans les industries de services au Canada. L'Actualité économique 77(2): 231254. https://doi.org/10.7202/602351ar

Mundlak, Y. 1978. On the Pooling of Time Series and Cross Section Data. Econometrica 46: 69-85. https://doi.org/10.2307/1913646

Pakes, A., and Z. Griliches. 1984. Patents and R\&D at the Firm Level: A First Look. In Z. Griliches (ed), R\&D, Patents, and Productivity. Chicago: University of Chicago Press. https://doi.org/10.3386/w0561

Pellegrino, G., and M. Savona. 2017. No Money, No Honey? Financial Versus Knowledge and Demand Constraints on Innovation. Research Policy 46(2): 510-521. https://doi.org/10.1016/j.respol.2017.01.001 
Savignac, F. 2008. Impact of Financial Constraints on Innovation: What Can Be Learned from a Direct Measure? Economics of Innovation and New Technology 17(6): 553-569. https:/doi. org/10.1080/10438590701538432

Schubert, T. 2010. Marketing and Organizational Innovations in Entrepreneurial Innovation Processes and their Relation to Market Structure and Firm Characteristics. Review of Industrial Organization 36(2): 189-212. https://doi.org/10.1007/s11151-010-9243-y

Segarra-Blasco, A., J. García-Quevedo, and M. Teruel-Carrizosa. 2008. Barriers to Innovation and Public Policy in Catalonia. International Entrepreneurship and Management Journal 4(4): 431-451. https://doi.org/10.1007/s11365-008-0086-Z
Solow, R. M. 1957. Technical Change and the Aggregate Production Function. Review of Economics and Statistics 39: 312-320. https:// doi.org/10.2307/1926047.

Tourigny, D., and C. D. Le. 2004. Impediments to Innovation Faced by Canadian Manufacturing Firms. Economics of Innovation and New Technology 13(3): 217-250. https://doi.org/10.1080/104385904 10001628387

Wooldridge, J. M. (2002). Econometric analysis of cross section and panel data. Cambridge, Mass: MIT Press.

Woolthuis, R. K., M. Lankhuizen, and V. Gilsing. 2005. A System Failure Framework for Innovation Policy Design. Technovation 25(6): 609-619. https://doi.org/10.1016/j.technovation.2003.11.002 


\section{Appendix}

Table A1. Sectoral Composition of the Firms in the Relevant Sample

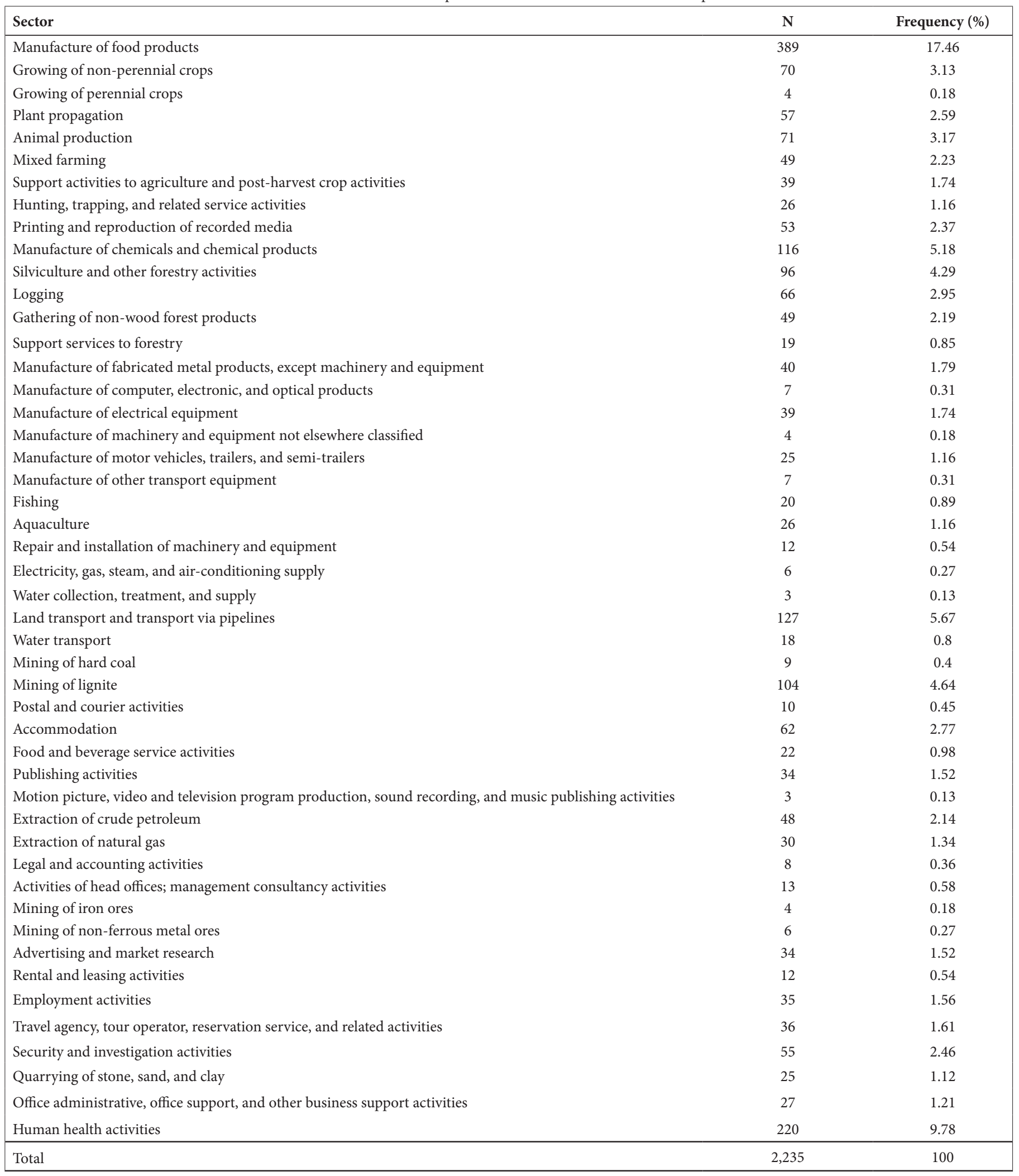


Table A2: Mean Differences between Public and Non-Public Companies in Innovation Investment and Size

\begin{tabular}{|lcc|}
\hline & Non-Public & Public \\
\hline Total investment in innovation activities (current USD) & 434,413 & $14,278,844$ \\
Investment in R\&D & 24,202 & $-13,844,431^{\star * *}$ \\
Investment in equipment & 381,460 & $-965,427^{\star * *}$ \\
Investment in other innovation activities & 28,751 & $11,267,171$ \\
Size & 231 & $2,022,043$ \\
\hline
\end{tabular}

Table A3. Effect of Barriers to Innovation on Innovation Propensity and Intensity (Full Sample)

\begin{tabular}{|c|c|c|c|c|c|}
\hline AI (probability of investing in innovation $\mathrm{IE}>0$ ) & $\begin{array}{l}1) \\
\text { All }\end{array}$ & $\begin{array}{c}(2) \\
\text { Industry }\end{array}$ & $\begin{array}{c}(3) \\
\text { Services }\end{array}$ & $\begin{array}{c}(4) \\
\text { Tangibles } \\
\end{array}$ & $\begin{array}{c}5) \\
\text { Intangibles }\end{array}$ \\
\hline \multirow[t]{2}{*}{ Financial Obstacles } & -0.017 & -0.017 & -0.012 & 0.007 & -0.030 \\
\hline & $(0.021)$ & $(0.027)$ & $(0.033)$ & $(0.021)$ & $(0.021)$ \\
\hline \multirow[t]{2}{*}{ Knowledge Obstacles } & 0.029 & 0.016 & 0.050 & 0.032 & $0.054^{* * *}$ \\
\hline & $(0.021)$ & $(0.028)$ & $(0.032)$ & $(0.021)$ & $(0.021)$ \\
\hline \multirow[t]{2}{*}{ Market Obstacles } & $0.041^{\star *}$ & 0.039 & 0.009 & 0.005 & 0.031 \\
\hline & $(0.020)$ & $(0.027)$ & $(0.031)$ & $(0.020)$ & $(0.020)$ \\
\hline \multirow[t]{2}{*}{ Institutional Obstacles } & 0.011 & 0.052 & -0.067 & 0.014 & 0.044 \\
\hline & $(0.029)$ & $(0.036)$ & $(0.049)$ & $(0.029)$ & $(0.028)$ \\
\hline \multirow[t]{2}{*}{ Context Obstacles } & -0.026 & 0.000 & $-0.072^{*}$ & -0.038 & -0.021 \\
\hline & $(0.025)$ & $(0.030)$ & $(0.041)$ & $(0.025)$ & $(0.024)$ \\
\hline \multirow[t]{2}{*}{$\ln$ (Age) } & -0.009 & 0.051 & $-0.129^{*}$ & 0.016 & 0.016 \\
\hline & $(0.055)$ & $(0.077)$ & $(0.075)$ & $(0.054)$ & $(0.053)$ \\
\hline $\ln ($ Size $)$ & $\begin{array}{l}0.102^{\star * *} \\
(0.010)\end{array}$ & $\begin{array}{c}0.150^{* * *} \\
(0.017)\end{array}$ & $\begin{array}{c}0.100^{\star * *} \\
(0.012)\end{array}$ & $\begin{array}{c}0.097^{\star * *} \\
(0.010)\end{array}$ & $\begin{array}{c}0.083^{\star * *} \\
(0.010)\end{array}$ \\
\hline \multirow[t]{2}{*}{ Exporter } & 0.023 & 0.025 & 0.030 & -0.014 & 0.047 \\
\hline & $(0.042)$ & $(0.054)$ & $(0.062)$ & $(0.042)$ & $(0.041)$ \\
\hline \multirow[t]{2}{*}{ High education } & 0.001 & $0.006^{* *}$ & -0.000 & 0.001 & 0.001 \\
\hline & $(0.001)$ & $(0.003)$ & $(0.002)$ & $(0.001)$ & $(0.001)$ \\
\hline \multicolumn{6}{|l|}{ IE (log of innovation expenditure per employee) } \\
\hline \multirow[t]{2}{*}{ Financial Obstacles } & -0.110 & -0.156 & -0.052 & 0.013 & -0.182 \\
\hline & $(0.148)$ & $(0.195)$ & $(0.227)$ & $(0.144)$ & $(0.121)$ \\
\hline \multirow[t]{2}{*}{ Knowledge Obstacles } & 0.161 & 0.124 & 0.336 & 0.155 & $0.217^{\star}$ \\
\hline & $(0.150)$ & $(0.194)$ & $(0.226)$ & $(0.146)$ & $(0.121)$ \\
\hline \multirow[t]{2}{*}{ Market Obstacles } & $0.333^{* *}$ & 0.233 & 0.154 & 0.102 & $0.353^{* * *}$ \\
\hline & $(0.145)$ & $(0.208)$ & $(0.243)$ & $(0.141)$ & $(0.118)$ \\
\hline \multirow[t]{2}{*}{ Institutional Obstacles } & 0.057 & 0.325 & $-0.561^{\star}$ & 0.019 & $0.296^{*}$ \\
\hline & $(0.205)$ & $(0.282)$ & $(0.321)$ & $(0.199)$ & $(0.165)$ \\
\hline \multirow[t]{2}{*}{ Context Obstacles } & -0.193 & -0.089 & -0.359 & -0.201 & -0.021 \\
\hline & $(0.176)$ & $(0.233)$ & $(0.296)$ & $(0.172)$ & $(0.144)$ \\
\hline \multirow[t]{2}{*}{$\ln$ (Age) } & 0.121 & 0.164 & -0.602 & 0.233 & 0.116 \\
\hline & $(0.371)$ & $(0.723)$ & $(0.567)$ & $(0.356)$ & $(0.297)$ \\
\hline \multirow[t]{2}{*}{$\ln ($ Size $)$} & $0.549^{* * *}$ & $1.236^{* * *}$ & $0.435^{\star * *}$ & $0.501^{* * *}$ & $0.356^{* * *}$ \\
\hline & $(0.054)$ & $(0.173)$ & $(0.061)$ & $(0.053)$ & $(0.044)$ \\
\hline \multirow[t]{2}{*}{ Exporter } & 0.089 & 0.103 & 0.116 & -0.124 & 0.184 \\
\hline & $(0.297)$ & $(0.360)$ & $(0.347)$ & $(0.287)$ & $(0.242)$ \\
\hline \multirow[t]{2}{*}{ High education } & 0.006 & $0.041^{\star *}$ & -0.001 & 0.004 & 0.002 \\
\hline & $(0.009)$ & $(0.019)$ & $(0.009)$ & $(0.009)$ & $(0.008)$ \\
\hline Observations & 2,708 & 1,512 & 1,196 & 2,708 & 2,708 \\
\hline Number of obs & 2708 & 1512 & 1196 & 2708 & 2708 \\
\hline Censored obs & 1273 & 652 & 621 & 1534 & 1588 \\
\hline Log pseudo likelihood & -4682 & -2625 & -1943 & -4191 & -4217 \\
\hline LR test of independence & 37.73 & 30.15 & 51.22 & 36.50 & 17.18 \\
\hline Year fixed effects & YES & YES & YES & YES & YES \\
\hline Within mean of independent variables & YES & YES & YES & YES & YES \\
\hline
\end{tabular}

Note: ${ }^{* *},{ }^{* *}$, and ${ }^{*}$ indicate significance at the 1 percent, 5 percent, and 10 percent levels respectively. Robust standard errors in parentheses. In columns 1,2 , and 3 the dependent variables are log expenditure in total innovation activities and a binary indicator that takes the value of 1 if the investment of the firm is greater than 0 . Columns 4 and 5 are analogous for the investment in tangibles and intangibles activities respectively. 
Table A4. Effect of Barriers to Innovation on Innovation Outcomes (Full Sample)

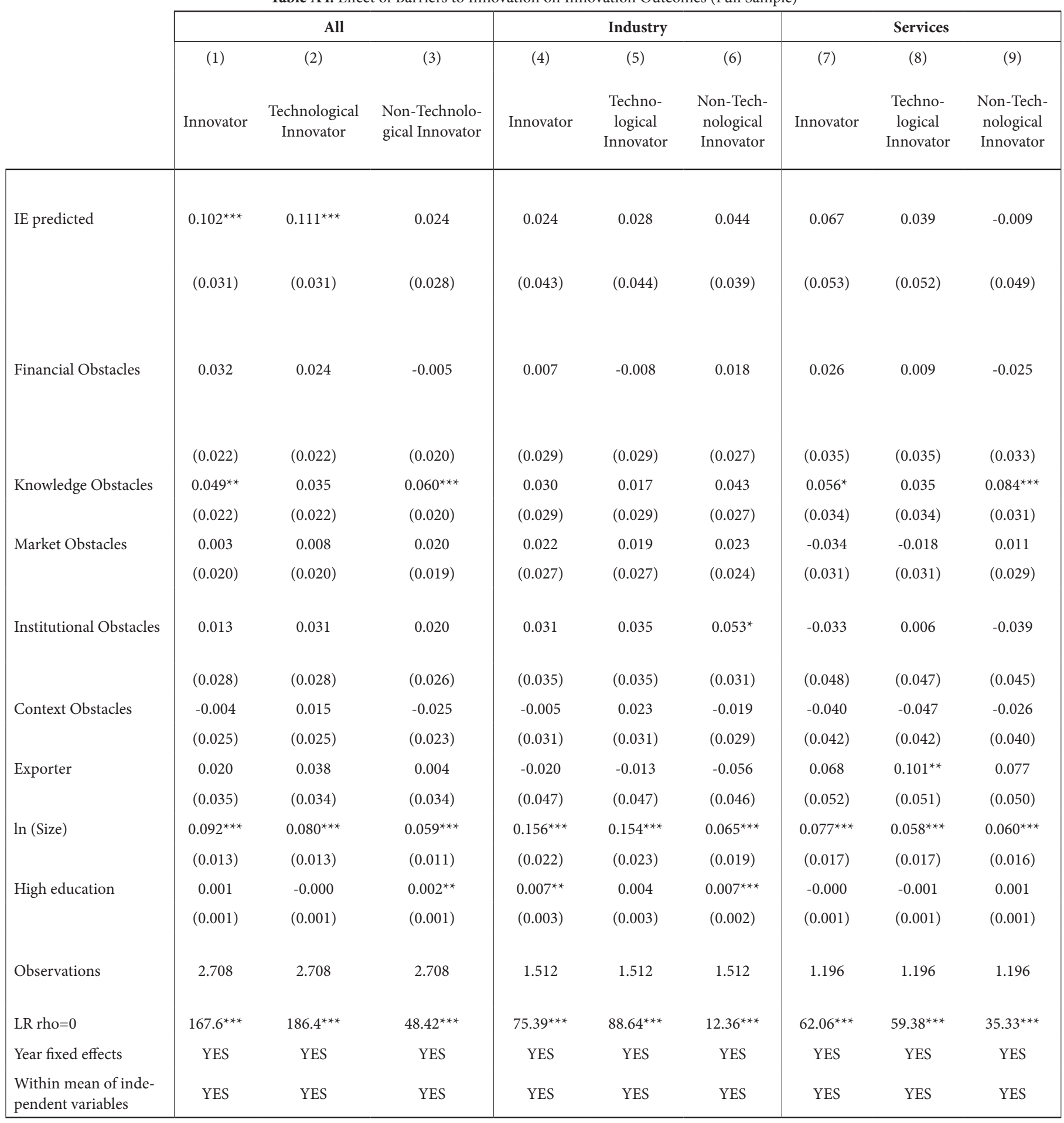

Note: ${ }^{* *}, * *$, and ${ }^{*}$ indicate significance at the 1 percent, 5 percent, and 10 percent levels respectively. In each column the dependent variable is a dummy that takes the value of 1 if the firm successfully introduced innovation and 0 otherwise. 
Table A4. Effect of Barriers to Innovation on Labor Productivity (Full Sample)

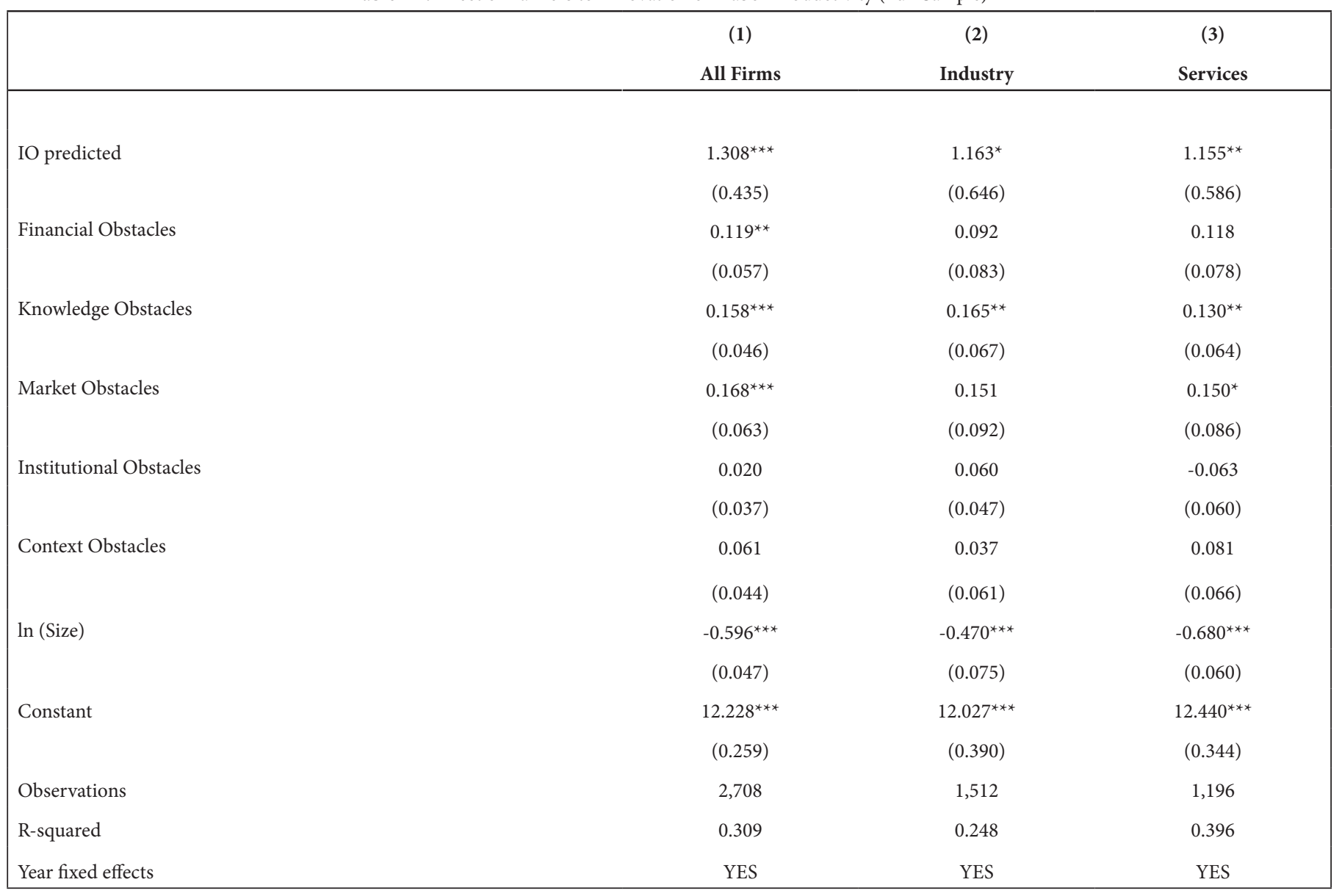

Note: ${ }^{* *},{ }^{* *}$, and ${ }^{*}$ indicate significance at the 1 percent, 5 percent, and 10 percent levels respectively. In all columns the dependent variable is the natural logarithm of labor productivity. 
